\title{
Micro-Water Harvesting and Soil Amendment Increase Grain Yields of Barley on a Heavy-Textured Alkaline Sodic Soil in a Rainfed Mediterranean Environment
}

\author{
Edward G. Barrett-Lennard 1,2,3,*, Rushna Munir ${ }^{4}$, Dana Mulvany ${ }^{4}$, Laine Williamson ${ }^{4}$, Glen Riethmuller ${ }^{4}$, \\ Callum Wesley ${ }^{5}$ and David Hall ${ }^{6}$
}

check for

updates

Citation: Barrett-Lennard, E.G.; Munir, R.; Mulvany, D.; Williamson, L.; Riethmuller, G.; Wesley, C.; Hall, D. Micro-Water Harvesting and Soil Amendment Increase Grain Yields of Barley on a Heavy-Textured Alkaline Sodic Soil in a Rainfed Mediterranean Environment. Agronomy 2021, 11, 713 https://doi.org/10.3390/ agronomy 11040713

Academic Editor: Angela Libutti

Received: 9 March 2021

Accepted: 6 April 2021

Published: 8 April 2021

Publisher's Note: MDPI stays neutral with regard to jurisdictional claims in published maps and institutional affiliations.

Copyright: (c) 2021 by the authors. Licensee MDPI, Basel, Switzerland. This article is an open access article distributed under the terms and conditions of the Creative Commons Attribution (CC BY) license (https:/ / creativecommons.org/licenses/by/ $4.0 /)$.
1 Department of Primary Industries and Regional Development, South Perth, WA 6151, Australia 2 Centre for Sustainable Farming Systems, Murdoch University, Murdoch, WA 6150, Australia

3 School of Agriculture and Environment, The University of Western Australia, Nedlands, WA 6009, Australia

4 Department of Primary Industries and Regional Development, Merredin, WA 6415, Australia; rushna.munir@dpird.wa.gov.au (R.M.); dana.mulvany@dpird.wa.gov.au (D.M.);

laine.williamson@dpird.wa.gov.au (L.W.); glen.riethmuller@dpird.wa.gov.au (G.R.)

5 Independent Researcher, P.O. Box 30, Southern Cross, WA 6426, Australia; cwesley@live.com.au

6 Department of Primary Industries and Regional Development, Esperance, WA 6450, Australia; david.hall@dpird.wa.gov.au

* Correspondence: ed.barrett-lennard@dpird.wa.gov.au

\begin{abstract}
This paper focuses on the adverse effects of soil sodicity and alkalinity on the growth of barley (Hordeum vulgare L.) in a rainfed environment in south-western Australia. These conditions cause the accumulation of salt (called 'transient salinity') in the root zone, which decreases the solute potential of the soil solution, particularly at the end of the growing season as the soil dries. We hypothesized that two approaches could help overcome this stress: (a) improved micro-water harvesting at the soil surface, which would help maintain soil hydration, decreasing the salinity of the soil solution, and (b) soil amelioration using small amounts of gypsum, elemental sulfur or gypsum plus elemental sulfur, which would ensure greater salt leaching. In our experiments, improved micro-water harvesting was achieved using a tillage technique consisting of exaggerated mounds between furrows and the covering of these mounds with plastic sheeting. The combination of the mounds and the application of a low rate of gypsum in the furrow $\left(50 \mathrm{~kg} \mathrm{ha}^{-1}\right)$ increased yields of barley grain by $70 \%$ in 2019 and by $57 \%$ in 2020, relative to a control treatment with conventional tillage, no plastic sheeting and no amendment. These increases in yield were related to changes in ion concentrations in the soil and to changes in apparent electrical conductivity measured with the EM38.
\end{abstract}

Keywords: electromagnetic induction; $\mathrm{EC}_{1: 5}$; EM38; gypsum; plastic mulch; sodicity; elemental sulfur; transient salinity

\section{Introduction}

This paper focuses on the growth of barley (Hordeum vulgare L.) on a sodic alkaline soil (Vertic Calcic Calcisol) affected by transient salinity and the ability of micro-water harvesting and soil amendment with combinations of gypsum and elemental sulfur to increase yield.

Soil sodicity is a constraint of global significance. It has recently been estimated that sodicity, expressed as an exchangeable sodium percentage (ESP) greater than $6 \%$, occurs in surface soils $(0-30 \mathrm{~cm})$ in at least $75 \%$ of years on approximately $9.2 \mathrm{Mkm}^{2}$ of land, with the most severely affected continents being Asia, Africa and Australia [1]. Soil alkalinity is also important in semi-arid landscapes. Global-scale soil surveys show that the predominant factor determining soil $\mathrm{pH}$ is climate; in general, there is an abrupt transition from acid to alkaline $\mathrm{pH}$ values at the point where mean annual precipitation falls below mean annual potential evapotranspiration [2]. 
Sodicity $[3,4]$ and alkalinity $[5,6]$ both increase soil dispersion, but for different reasons. In many Australian soils, the dominant clay is kaolinite [7], which consists of platelet-like crystals approximately $390-560 \mathrm{~nm}$ in diameter and $60-120 \mathrm{~nm}$ in thickness [8]. The faces of these platelets are negatively charged. However, at neutral $\mathrm{pH}$, their edges are positively charged [9]. When kaolinitic particles cluster together, they flocculate; there are two mechanisms for this: lamellar ('face to face') flocculation, and 'edge-to-face' flocculation [9]. Lamellar flocculation requires the repulsive forces of the clouds of cations occupying the space between adjacent clay faces to be overcome: this can be achieved by increasing the electrolyte concentration and by increasing concentrations of divalent calcium ions in this space [10]. 'Edge-to-face' flocculation depends on the electrostatic attraction of negatively charged platelet faces with positively charged edges; however, when the soil becomes alkaline, the positive charges on the edges become surrounded by hydroxyl ions, the net positive charges on the edges are lost, 'edge-to-face' flocculation ceases, and the clay disperses [11].

One consequence of dispersion in the sodic and alkaline dispersive soils of semi-arid landscapes is the accumulation of salt ("transient salinity") in the profile $[5,12]$. The adverse effects of soil dispersion on crop growth may in fact be caused by transient salinity. Given sufficient concentration, salts in a soil will adversely affect the growth of all agricultural crops $[13,14]$. However, the factor that actually decreases crop yield in saline soils is not the salt concentration of the soil but the salinity of the soil solution, which is the ratio of salt to water in the soil [12]. Elevated salinities of the soil solution adversely affect crop growth by decreasing the osmotic potential of the soil solution and by increasing the concentration of toxic ions in the soil solution $[12,15,16]$. The degree of stress is proportional to the concentration of salt in the soil, but also increases exponentially as the concentration of water in the soil declines [17-19]. We therefore considered it likely that the adverse effects of transient salinity on crop growth could be ameliorated by increasing soil hydration (using micro-water harvesting) and by decreasing, through leaching, salt concentrations in the soil (using amendment with gypsum or elemental sulfur) c.f. [20-26].

The salts associated with transient salinity either fall in the rain $[27,28]$ or derive from the weathering of high-sodium rocks [12] and increase in concentration in the root zone in soils that disperse [5,12]. Based on measurements of the concentration of $\mathrm{Cl}^{-}$in rainwater and average annual rain statistics, it has been estimated that the salt stored in the upper $1 \mathrm{~m}$ of a typical sodic alkaline soil in Western Australia would have taken approximately 1300 years to accumulate [5].

It seems likely that the independent effects of sodicity and alkalinity on salt accumulation are caused by effects of dispersion on saturated hydraulic conductivity $\left(\mathrm{K}_{\mathrm{s}}\right)$. In column experiments with a kaolinitic soil perfused with an electrolyte solution of $50 \mathrm{mmol} \mathrm{L}^{-1}$ of charge and a Sodium Adsorption Ratio (SAR) of 20, increasing the $\mathrm{pH}$ from 6 to 8 caused a $43 \%$ decrease in $K_{s}$. However, when the SAR was increased to 40 at the same electrolyte concentration, increasing the $\mathrm{pH}$ from 6 to 8 caused an $97 \%$ decrease in $\mathrm{K}_{\mathrm{s}}$ [29]. Results such as these suggest that sodicity and alkalinity interact in their adverse effects on soils.

The work described in the present paper is based around three themes: firstly, the ability of surface water harvesting and soil amendment to improve crop growth and yield, secondly the impacts of these treatments on transient salinity and soil chemistry, and thirdly relationships between variation in soil apparent electrical conductivity, grain yield and soil chemistry.

Regarding Theme 1 (improving crop growth and grain yield), we have been experimenting with approaches that address the issues of soil hydration and salt leaching in sodic alkaline soils using: (a) exaggerated soil mounding and plastic sheeting to increase surface water harvesting and improve the water content of the soil, and (b) the application of soil amendments (such as gypsum and elemental sulfur) that reverse dispersion. The present work marks the convergence of these two approaches in a field trial. We hypothesized that the grain yield of barley would be improved by micro-water harvesting at the soil surface 
(H1), and by soil amendment with small rates of application of gypsum, elemental sulfur, or gypsum plus elemental sulfur (H2).

Regarding Theme 2 (effects of treatments on transient salinity and soil chemistry), previous work has shown that the salinity of the soil $\left(\mathrm{EC}_{1: 5}\right)$ is affected by soil sodicity and soil $\mathrm{pH}[5,6]$. However, it is not actually known which ions are most associated with transient salinity, how soil amendments affect these ions, and how these changes correlate with grain yield. We hypothesized (H3) that micro-water harvesting and soil amendment would affect crop yield because they decreased ion concentrations in the soil profile.

Regarding Theme 3 (relationships between variation in soil apparent electrical conductivity, grain yield and soil chemistry), electromagnetic induction (measured with instruments such as the Geonics EM38 or DualEM) has been used to survey variation in soil salinity at the landscape scale since the 1980s [30]. Readings, referred to as measures of the apparent electrical conductivity $\left(\mathrm{EC}_{\mathrm{a}}\right)$, are known to respond positively to increasing solute concentration in soils, and also respond to soil water and clay contents [31]. Surveys on sodic alkaline soils with electromagnetic induction have shown spatial variation in apparent electrical conductivity at the paddock scale [5]. We used the EM38 to survey our plots in the spring of each year. We hypothesized that readings would be affected by amendment and tillage treatments (H4), be correlated with grain yield (H5), and be correlated with soil chemistry (H6).

\section{Materials and Methods}

\subsection{Location}

The trial was sown on a sandy clay Calcic Calcarosol (Australian Soil Classification) [32] or Vertic Calcic Calcisol (Sodic) (World Reference Base) [33] on Merredin Research Station $\left(-31^{\circ} 30^{\prime} 25^{\prime \prime} \mathrm{S}, 118^{\circ} 13^{\prime} 04^{\prime \prime} \mathrm{E}\right)$ in 2019 ; there was a repeat application of treatments with sowing over the same plots in 2020. There is strong patterning of apparent electrical conductivity $\left(\mathrm{EC}_{\mathrm{a}}\right)$ measured with the DualEM $1 \mathrm{~S}$ at the paddock scale in alkaline sodic soils in this area [5]. To locate our trial site, we conducted a DualEM 1S survey across six paddocks at the Research Station on 9 April 2019 (Figure 1). A number of locations with high $\mathrm{EC}_{\mathrm{a}}$ were identified from this survey and we selected the site for the trial at the place indicated in Figure 1.

\subsection{Trial Design and Management}

The trial had a factorial design, with two tillage treatments (conventional tillage or tillage with a 'mounded' interrow with plastic sheeting over the top of the mounds), four amendment treatments (nil, application of gypsum $(G)$, application of elemental sulfur (ES), or application of gypsum plus elemental sulfur $(\mathrm{G}+\mathrm{ES})$ ), and four replicates. The plots were laid out in 8 ranges (running east-west), with 4 plots per range (running north-south). Running east-west, every two adjacent ranges either had conventional cultivation or the mounded tillage treatment. Running north-south, adjacent pairs of plots within pairs of ranges had the same amendment (nil, G, ES or G+ES). Amendments were applied to the 4 pairs of tillage combination (running east-west) and the 4 plots (running north-south) using a Latin square design.

Each plot was $8 \mathrm{~m}$ in length, the width between plot centers was $2.4 \mathrm{~m}$, and there were 5 rows per plot at $375 \mathrm{~mm}$ spacings. Measurements were made on the inner 3 rows of each plot. The mounding was achieved with a specially designed mechanical seeder that produced a mound with a slope of $25^{\circ}$ approximately $9 \mathrm{~cm}$ in height and $30 \mathrm{~cm}$ in width. After sowing, each mound was covered with strips of clear polythene sheeting, $0.5 \mathrm{~mm}$ in thickness, $8 \mathrm{~m}$ in length and $30 \mathrm{~cm}$ in width. Seed of barley (Hordeum vulgare, $\mathrm{cv}$ Spartacus) was sown at a rate of $70 \mathrm{~kg} \mathrm{ha}^{-1}$. In each year, the gypsum and elemental sulfur amelioration treatments were applied as part of the seeding operation at the time of sowing to the area of the furrow $\left(7.5 \mathrm{~cm}\right.$ in width) at rates of 50 and $77 \mathrm{~kg} \mathrm{ha}^{-1}$, respectively, (or 10 and $15.4 \mathrm{~kg} \mathrm{ha}^{-1}$, respectively, assuming that the furrow accounted for $20 \%$ of the soil surface area). The gypsum was applied with the seed; the elemental sulfur was applied 
approximately $5 \mathrm{~cm}$ deeper with the fertilizer. The soil sulfate concentration was greater than $3.1 \mathrm{mg} \mathrm{S} \mathrm{kg}^{-1}$ in the $0-30 \mathrm{~cm}$ range, indicating that the soil is not responsive to sulfur fertilizer application [34]. A basal S fertilizer was therefore not applied to the experiment.

\section{Longitude}

118.22 118.23

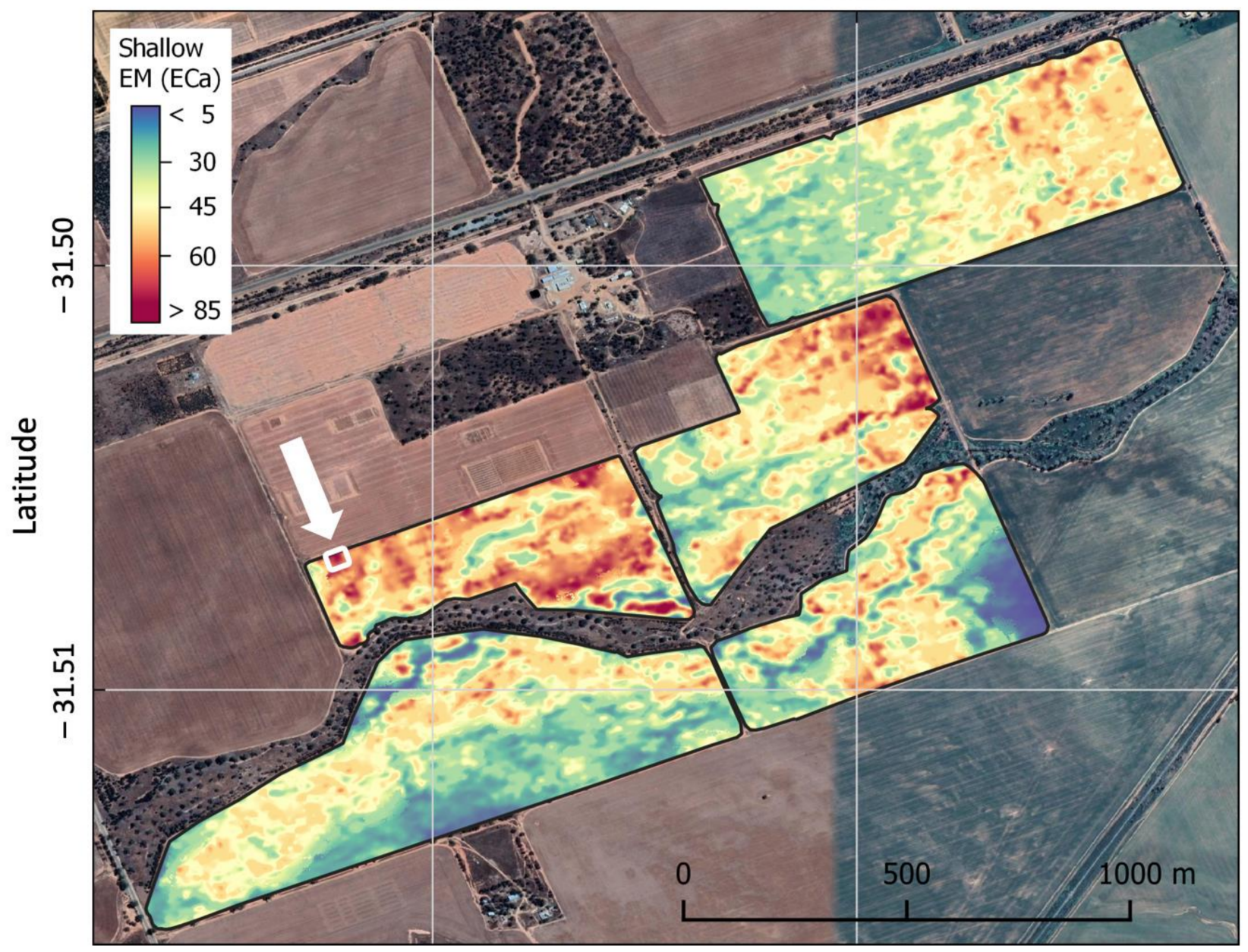

Figure 1. Variation in apparent electrical conductivity $\left(\mathrm{EC}_{\mathrm{a}}\right)$ measured at the paddock scale with a DualEM (the $50 \mathrm{~cm}$ dipole) at Merredin Research Station on 9 April 2019. The trial was located in the white square indicated by the arrow.

The trial was sown on 17 June 2019 and again on 21 May 2020. In both years, monoammonium phosphate with copper and zinc $(11.6 \% \mathrm{~N}, 3 \% \mathrm{~S}, 21 \% \mathrm{P}, 0.05 \% \mathrm{Cu}, 0.10 \% \mathrm{Zn})$ was applied at seeding at $40 \mathrm{~kg} \mathrm{ha}^{-1}$. Later surface applications of $\mathrm{N}$ occurred as urea in 2019 on 9 August (13.8 kg N ha $\left.{ }^{-1}\right)$, and in 2020 on 2 July (13.8 kg N ha $\left.{ }^{-1}\right)$, 3 August (18.4 $\mathrm{kg} \mathrm{N} \mathrm{ha}^{-1}$ ) and 14 August $\left(9.2 \mathrm{~kg} \mathrm{~N} \mathrm{ha}^{-1}\right)$.

Green leaf cover was estimated at approximately two weekly intervals throughout each growing season by photographing each plot at three locations; the images were processed using the Canopeo method [35] to determine the areal percentage of green in the photo. The images were processed in MATLAB (MathWorks, Natick, MA, USA).

Biomass cuts ( $1 \mathrm{~m}$ of row at three locations within each $8 \mathrm{~m}$ plot) were taken when the crop was at anthesis on 23 September 2019 and 2 September 2020, and final harvest cuts (also $1 \mathrm{~m}$ of row at three locations) were taken on 19 November 2019 and 27-28 October 2020. Measurements were made of total shoot biomass at anthesis and final harvest, total grain yield, 1000 grain weight and the number of tillers with heads. 


\subsection{Soil Sampling and Analysis}

Soil was sampled with a percussion drill rig ( 1 hole per plot) on three occasions: 18 July 2019 (31 days after sowing in the first year), 29 April 2020 (22 days before sowing in the second year) and 13 August 2020 (84 days after sowing in the second year). On the first occasion, the soil was sampled to $70 \mathrm{~cm}(10 \mathrm{~cm}$ intervals to $30 \mathrm{~cm}$ and $20 \mathrm{~cm}$ intervals to $70 \mathrm{~cm}$ ). The sampled soil was oven dried, finely ground and analyzed by a commercial laboratory (CSBP Soils Laboratory, Bibra Lake, Australia). The methods of the analyses conducted are summarized in Table 1 . Measurements were made of $\mathrm{pH}_{\mathrm{H} 2 \mathrm{O}}$, $\mathrm{EC}_{1: 5}, \mathrm{SO}_{4}{ }^{2-}$ and boron. On the second occasion the soil was sampled to $70 \mathrm{~cm}$ (also $10 \mathrm{~cm}$ intervals to $30 \mathrm{~cm}$ and $20 \mathrm{~cm}$ intervals to $70 \mathrm{~cm}$ ), these variables were measured again and exchangeable cations were also determined. On the third occasion, the soil was sampled to $120 \mathrm{~cm}(20 \mathrm{~cm}$ intervals to $60 \mathrm{~cm}$ and $30 \mathrm{~cm}$ intervals to $120 \mathrm{~cm})$, and measurements were made of $\mathrm{pH}_{\mathrm{H} 2 \mathrm{O}}, \mathrm{EC}_{1: 5}$, a range of cations and anions were determined in water extracts, and measurements were also made of soil water. For the first and third surveys, a hole was dug over the central furrow in each plot either near the plot center (first survey) or near the north end (third survey). This enabled correlations to be made between soil chemistry and grain yield.

Table 1. Soil data collected at the three times of sampling.

\begin{tabular}{|c|c|c|c|c|}
\hline Analysis & $\begin{array}{c}\text { First } \\
\text { Sampling }\end{array}$ & $\begin{array}{c}\text { Secon } \\
\text { Sampling }\end{array}$ & $\begin{array}{c}\text { Third } \\
\text { Sampling }\end{array}$ & Method \\
\hline $\mathrm{pH}_{\mathrm{H} 2 \mathrm{O}} ; \mathrm{EC}_{1: 5}$ & $\checkmark$ & $\checkmark$ & $\checkmark$ & $\begin{array}{l}\text { Soil extracted in deionised water at a } \\
\text { ratio of 1:5, stirring for one hour. } \mathrm{pH} \\
\text { and EC of extract measured using a pH } \\
\text { and conductivity electrode [36] } \\
\text { (Methods 4A1 and 3A1). }\end{array}$ \\
\hline $\mathrm{SO}_{4}^{2-}$ & $\checkmark$ & $\checkmark$ & $\checkmark$ & $\begin{array}{c}\text { Soil extracted in } 0.25 \mathrm{M} \mathrm{KCl} \text {. S content } \\
\text { of extract analysed by inductively } \\
\text { coupled plasma (ICP) spectroscopy [36] } \\
\text { (Method 10D1). }\end{array}$ \\
\hline Boron & $\checkmark$ & $\checkmark$ & - & $\begin{array}{c}\text { Soil extracted in } 0.01 \mathrm{M} \mathrm{CaCl}_{2} \text {, in ratio } \\
\text { of } 1: 4 . \text { Mixture heated to } 90^{\circ} \mathrm{C} \text { and } \\
\text { extract read for boron using ICP } \\
\text { spectroscopy [36] (Method } 12 \mathrm{C} 2 \text { ). }\end{array}$ \\
\hline Exchangeable cations & - & $\checkmark$ & - & $\begin{array}{l}\text { Soil extracted using a mixture of } 0.1 \mathrm{M} \\
\mathrm{NH}_{4} \mathrm{Cl} \text { and } \mathrm{BaCl}_{2} \text { in ratio of } 1: 10 . \\
\text { Exchangeable cations in extract } \\
\text { determined using ICP spectroscopy } \\
\text { (Method 15E1). }\end{array}$ \\
\hline Soluble cations & - & - & $\checkmark$ & $\begin{array}{l}\text { Water soluble cations determined in a } \\
\text { 1:5 soil: water extraction. Cations in } \\
\text { extract determined using ICP } \\
\text { spectroscopy [36] (Method 5A4). }\end{array}$ \\
\hline Chloride & - & - & $\checkmark$ & $\begin{array}{l}\text { Water soluble chloride determined in a } \\
\text { 1:5 soil:water extraction. Chloride } \\
\text { concentration in extract determined } \\
\text { colorimetrically [36] (Method 5A2b). }\end{array}$ \\
\hline
\end{tabular}

\subsection{Electromagnetic Induction Surveys}

Electromagnetic induction surveys were conducted at the plot scale with an EM38 (Geonics Limited) in the horizontal orientation in the spring of each year (10 October 2019 and 21 September 2020). Each plot was surveyed over the middle furrow at three locations - the north end of the plot, the middle of the plot and the south end of the plot. In each year, one-third of these readings therefore overlapped with a soil survey position. 


\subsection{Other Data Sources}

Rainfall and reference evapotranspiration $\left(\mathrm{ET}_{\mathrm{o}}\right)$ data were accessed from the Scientific Information for Land Owners (SILO) database [37] for the Merredin Bureau of Meteorology weather station [38] located approximately $7 \mathrm{~km}$ east of the trial site.

\subsection{Statistical Analyses}

Statistical analyses (ANOVAs and regressions) were conducted using Genstat (18th edition, VSN International). ANOVAs were used to determine the significance of tillage and amendment treatments. Soil chemical parameters were analyzed in ANOVAs with tillage and amendment as variables and depth as a repeating measure. The following codes have been adopted indicating statistical significance: $\mathrm{ns}=$ not significant; ${ }^{*} p<0.05$; ${ }^{* *} p<0.01 ;{ }^{* * *} p<0.001$.

\section{Results}

\subsection{Rainfall and Reference Evapotranspiration}

Rainfall and reference evapotranspiration $\left(\mathrm{ET}_{\mathrm{o}}\right)$ data for 2019 and 2020 are reported in Table 2. The site has a typical Mediterranean climate, with wet winters of low evaporative demand and dry summers with high evaporative demand. In general, 2019 had less rainfall for crop growth than 2020, although plants were constrained by lack of moisture late in the growing season in each year. In 2019, there was $29 \mathrm{~mm}$ of pre-seasonal (February-April) rain, and $186 \mathrm{~mm}$ of seasonal rain (May-October), of which $23 \mathrm{~mm}$ fell in the period between anthesis and harvest. In 2020, there was $58 \mathrm{~mm}$ of pre-seasonal rain, and $212 \mathrm{~mm}$ of seasonal rain, of which $16 \mathrm{~mm}$ fell in the period between anthesis and harvest. In each year, $\mathrm{ET}_{\mathrm{o}}$ values were approximately $1.5 \mathrm{~mm} \mathrm{day}^{-1}$ in mid-winter (early July), rising to approximately $3-4 \mathrm{~mm}$ day $^{-1}$ during crop maturation (early October).

Table 2. Total monthly rainfall $(\mathrm{mm})$ and reference evapotranspiration $\left(\mathrm{ET}_{\mathrm{o}}\right)$ for 2019 and 2020.

\begin{tabular}{ccccc}
\hline \multirow{2}{*}{ Month } & \multicolumn{2}{c}{ Rain $(\mathbf{m m})$} & $\mathbf{2 0 1 9}$ & $\mathbf{E T}_{\mathbf{o}}(\mathbf{m m})$ \\
\cline { 2 - 5 } & $\mathbf{2 0 1 9}$ & $\mathbf{2 0 2 0}$ & 210 & $\mathbf{2 0 2 0}$ \\
\hline January & 0.6 & 0.2 & 178 & 201 \\
February & 0 & 44 & 150 & 155 \\
March & 6.4 & 9.7 & 95 & 130 \\
April & 22.8 & 3.8 & 71 & 102 \\
May & 5.8 & 64.8 & 45 & 66 \\
June & 67.2 & 41.6 & 50 & 51 \\
July & 37 & 36.1 & 66 & 49 \\
August & 52 & 48.6 & 106 & 61 \\
September & 3.6 & 19.9 & 144 & 90 \\
October & 20.6 & 1.2 & 189 & 141 \\
November & 2.2 & 48.2 & 225 & 200 \\
December & 0.2 & 13.2 & 1526 & 1393 \\
\hline Total & 215.4 & 269.7 & &
\end{tabular}

Data from weather station at Merredin $\left(-31^{\circ} 28^{\prime} 32^{\prime \prime} \mathrm{S}, 118^{\circ} 16^{\prime} 44^{\prime \prime} \mathrm{E}\right)[37,38]$.

\subsection{Theme 1-Improving Crop Growth and Grain Yield}

The effects of tillage and amendment treatments on barley grain yield in the two seasons are summarized in Table 3 Part A (data for 2019) and Part B (data for 2020). In overview, the combination of best treatments (mounding plus $\mathrm{G}$ amendment) increased grain yield by $70 \%$ in 2019 and by $57 \%$ in 2020 relative to the conventional plus nil amendment control (Table 3). The tillage by amendment interaction was not significant, indicating that the amendment treatments followed the same trend for the two tillage practices. 
Table 3. Effect on the grain yield and yield components of barley (H. vulgare) from tillage and amendment treatments in: (A) the 2019 growing season, and (B) the 2020 season. Values are the average of four measurements, with the standard error of the mean given in brackets. A statistical summary is given at the foot of each table.

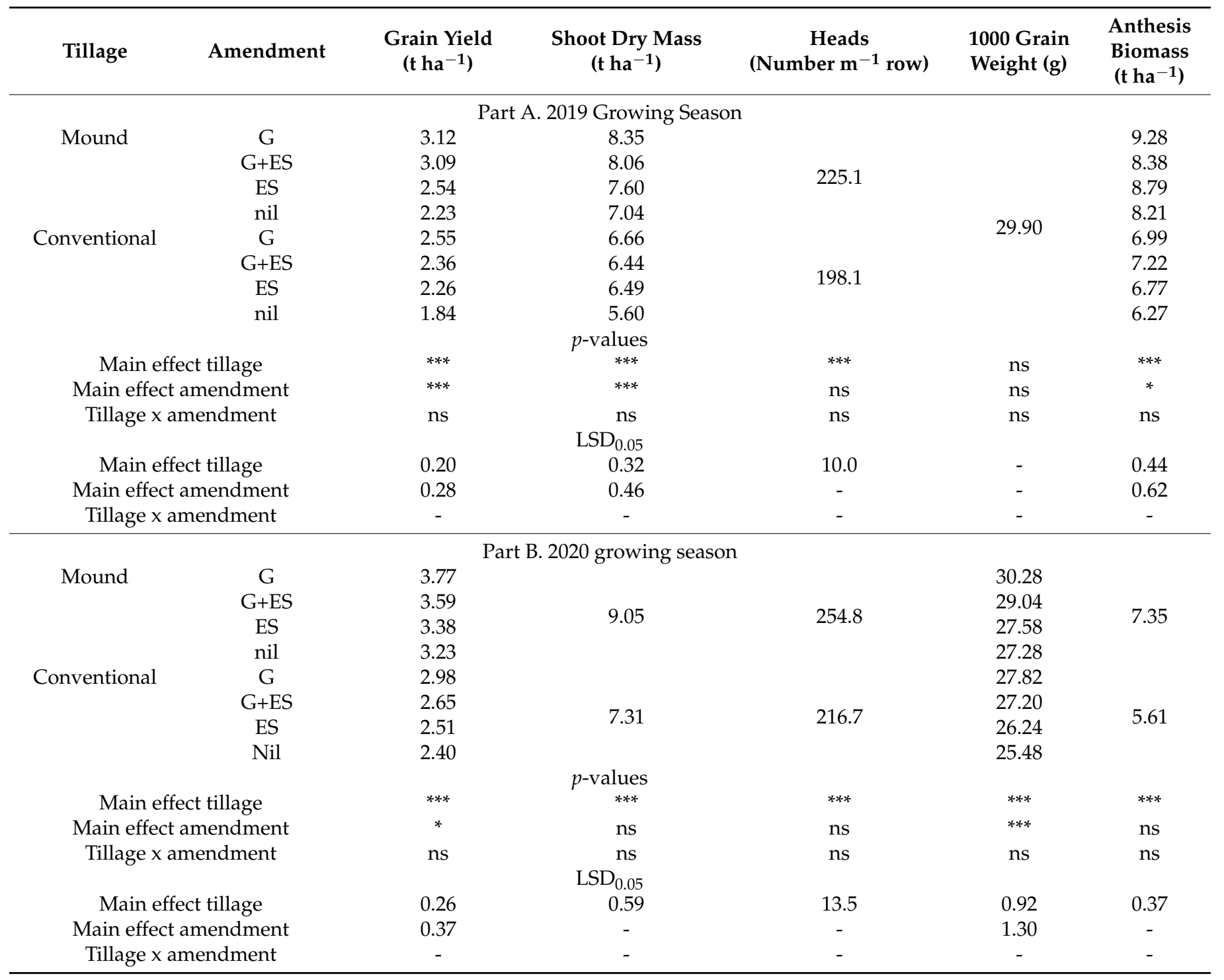

Amendments were: nil, gypsum (G), elemental sulfur (ES), and gypsum plus elemental sulfur (G+ES). The soil was a Vertic Calcic Calcisol located on Merredin Research Station $\left(-31^{\circ} 30^{\prime} 25^{\prime \prime}\right.$ S, $118^{\circ} 13^{\prime} 04^{\prime \prime}$ E). Statistical significance is as follows: $n s=$ not significant; * $p<0.05$; $* * * p<0.001$.

There were highly significant $(p<0.001)$ main effects of tillage, with the mounded treatment having higher growth than the conventional tillage treatment. Average values for the mounded treatment in 2019 and 2020 were $22 \%$ and $33 \%$ higher, respectively, for grain yield, $23 \%$ and $24 \%$ higher, respectively, for shoot dry mass (DM) at harvest, $14 \%$ and $18 \%$ higher, respectively, for heads per meter of row, and $27 \%$ and $31 \%$ higher, respectively, for shoot DM at anthesis. In addition, the 1000-grain weight was $7 \%$ higher with the mounding tillage than the conventional tillage in 2020.

There were also significant $(p<0.05$ or $p<0.001)$ main effects of soil amendment, with the gypsum $(\mathrm{G})$ amendment having higher growth, decreasing in the order $\mathrm{G}>\mathrm{G}+\mathrm{ES}>\mathrm{E} \mathrm{S}>$ nil. Average grain yields of the G compared to nil treatment were $28 \%$ and 20\% higher in 2019 and 2020, respectively. Average grain yields of the ES compared to nil treatment were $18 \%$ higher in 2019. In addition, in 2019, the shoot DM at harvest and the shoot DM at anthesis were $19 \%$ and $12 \%$ higher, respectively, with the $\mathrm{G}$ amendment than the nil treatment, and in 2020 the 1000-grain weight was $10 \%$ higher with the G amendment than nil treatment. 
A correlation of grain yields in 2019 (three samples per plot) with grain yields in 2020 (three samples per plot) was significant with a positive simple line of best fit $(p<0.001$; $r^{2}=0.281$ ) (Figure 2).

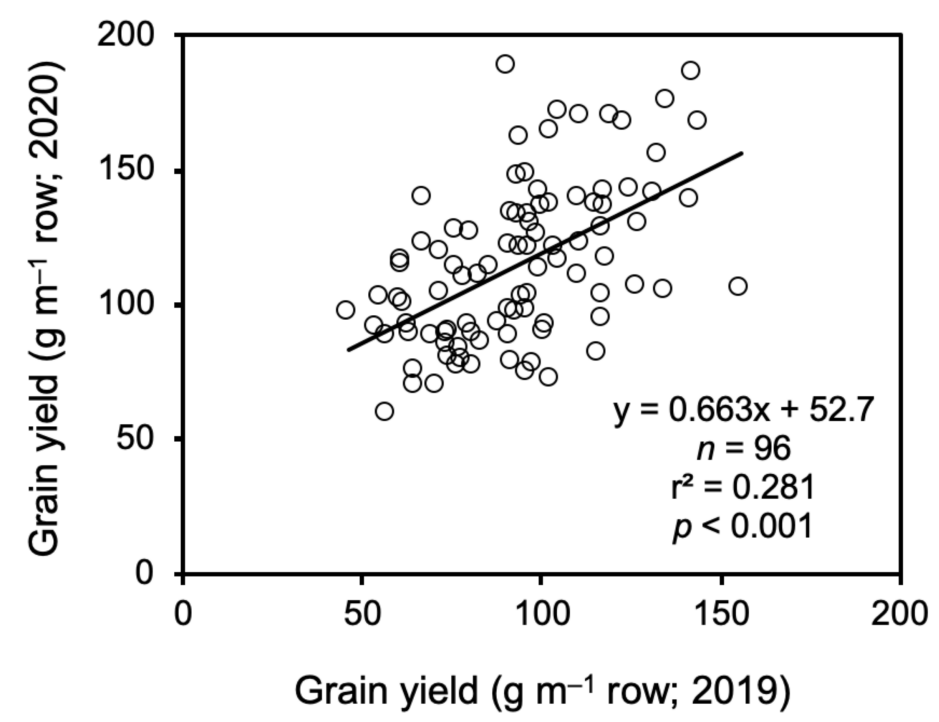

Figure 2. Correlation between grain yield data in 2019 and 2020. There were three points per plot. The soil was a Vertic Calcic Calcisol located on Merredin Research Station $\left(-31^{\circ} 30^{\prime} 25^{\prime \prime} \mathrm{S}, 118^{\circ} 13^{\prime} 04^{\prime \prime} \mathrm{E}\right)$.

The effects of tillage and amendment on green leaf cover during the 2019 and 2020 growing seasons are summarized in Figure 3A,B and Figure 3C,D, respectively. Green cover became measurable within a few weeks of sowing and reached a maximum in early September; it then declined as the leaves senesced. In each year, there were significant effects of tillage from the earliest dates of green cover measurement (Figure 3A,C). In contrast, with amendment, the impacts on green cover became most significant at the end of the growing season (Figure 3B,D). In both years, at the end of the growing season, the application of the gypsum amendment delayed leaf senescence.

\subsection{Theme 2-Effects of Treatments on Transient Salinity and Soil Chemistry}

\subsubsection{Overview}

The effects of soil depth, tillage and amendment treatments on the soil variables measured at the first, second and third times of sampling are summarized in the Supplementary Materials (Tables S1-S3, respectively).

A soil is considered saline if the electrical conductivity of the saturation extract $\left(\mathrm{EC}_{\mathrm{e}}\right)$ is above $4 \mathrm{dS} \mathrm{m}^{-1}$ [39]. For a sandy clay, this equates to an $\mathrm{EC}_{1: 5}$ of approximately $0.47 \mathrm{dS} \mathrm{m}^{-1}$, based on the conversion factor of Slavich and Petterson [40]. In overview (Table 4), the soil analyses showed that the soil was sodic (ESP values greater than 6\%) [41], alkaline $\left(\mathrm{pH}_{\mathrm{H} 2 \mathrm{O}}\right.$ values greater than 7$)$, and affected by salinity at depth $\left(\mathrm{EC}_{1: 5}\right.$ values greater than $0.47 \mathrm{dS} \mathrm{m}^{-1}$ ).

For each of the series of samplings, there were two factors of overall importance. The most impressive aspect of soil chemistry was that for all ions measured, there was a highly significant $(p<0.001)$ effect of depth in the soil profile. At the first time of sampling (Supplementary Materials-Table S1), with $\mathrm{EC}_{1: 5}, \mathrm{SO}_{4}{ }^{2-}$ and boron, average values increased 3.8-5.5 fold as depth increased from 0-10 to 50-70 $\mathrm{cm}$. At the second time of sampling (Supplementary Materials-Table S2), with $\mathrm{EC}_{1: 5}, \mathrm{SO}_{4}{ }^{2-}$, boron and $\mathrm{Na}^{+}$exch, average values increased 2.6-6.6 fold as depth increased from 0-20 to $50-70 \mathrm{~cm}$. At the third time of sampling (Supplementary Materials-Table S3), with $\mathrm{Na}^{+}, \mathrm{SO}_{4}{ }^{2-}$, and $\mathrm{Cl}^{-}$, average concentrations were $7.9-10.2$ fold higher at $90-120 \mathrm{~cm}$ than at $0-0 \mathrm{~cm}$, and $\mathrm{Mg}^{2+}$, $\mathrm{K}^{+}$, the $\mathrm{EC}_{1: 5}$ and $\mathrm{Ca}^{2+}$ were $2.5-5.3$ fold higher at $90-120$ than at $0-10 \mathrm{~cm}$. 

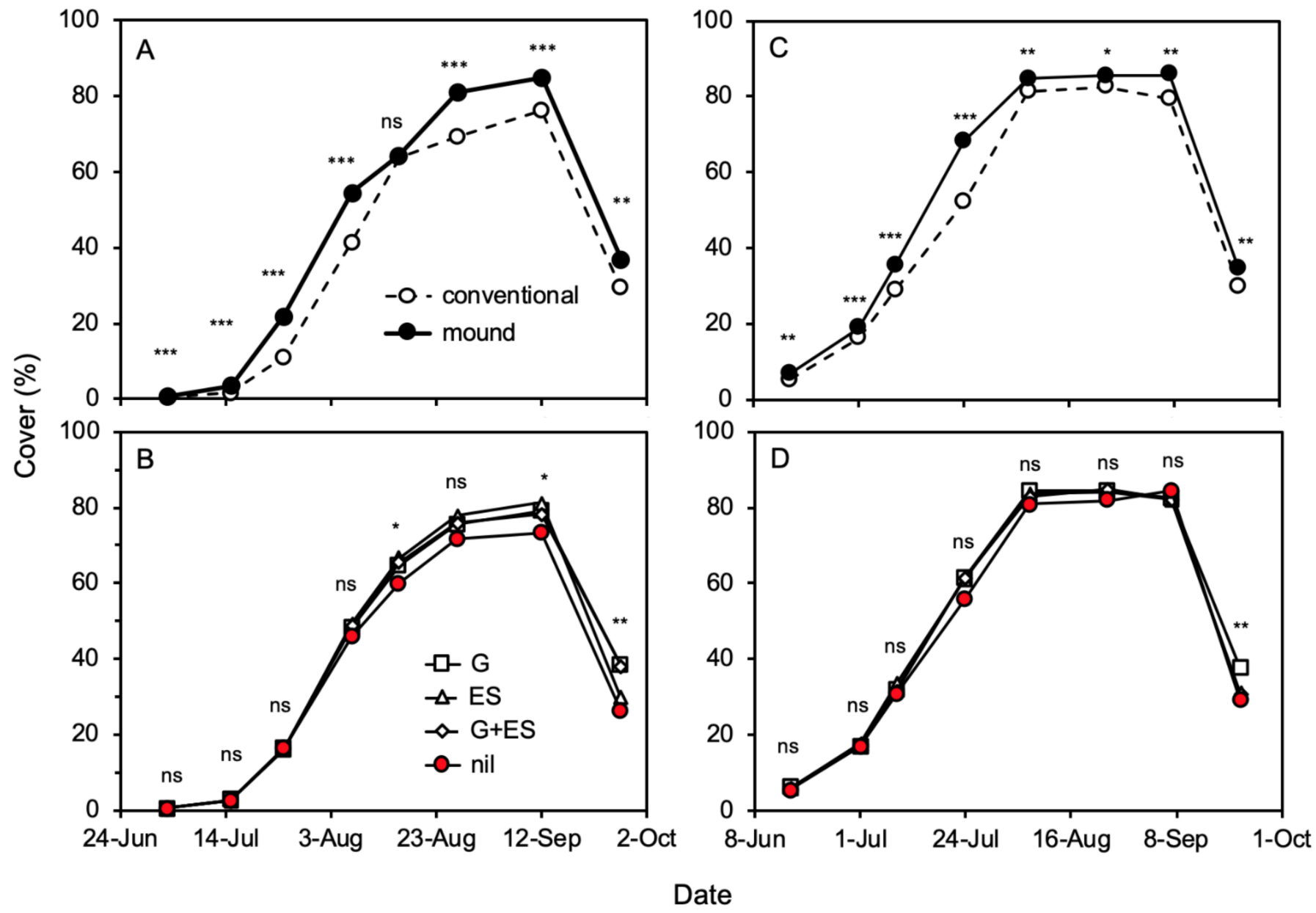

Figure 3. Effect on green leaf cover by barley of tillage (A,C) and amendment $(\mathbf{B}, \mathbf{D})$ in the 2019 growing season $(\mathbf{A}, \mathbf{B})$, and the 2020 season $(\mathbf{C}, \mathbf{D})$. Each point is the average of $16(\mathbf{A}, \mathbf{C})$ or 8 values $(\mathbf{B}, \mathbf{D})$. The significance of treatment comparisons is indicated at each date. Amendments were: nil, gypsum (G), elemental sulfur (ES), and gypsum plus elemental sulfur (G+ES). The soil was a Vertic Calcic Calcisol located on Merredin Research Station $\left(-31^{\circ} 30^{\prime} 25^{\prime \prime} \mathrm{S}, 118^{\circ} 13^{\prime} 04^{\prime \prime}\right.$ E). Statistical significance is as follows: $\mathrm{ns}=$ not significant; ${ }^{*} p<0.05 ;{ }^{* *} p<0.01 ;{ }^{* * *} p<0.001$.

Table 4. Selected properties (based on average values across all treatments) at the three times of soil sampling. The data for these samplings are given in the Supplementary Materials, Tables S1-S3.

\begin{tabular}{cccc}
\hline \multirow{2}{*}{ Variable } & \multicolumn{3}{c}{ Time of Sampling } \\
\cline { 2 - 4 } & First & Second & Third \\
\hline $\mathrm{ESP}>6 \%$ & ND & All depths & ND \\
$\mathrm{pH}_{\mathrm{H} 2 \mathrm{O}}>7$ & All depths & All depths & All depths \\
$\mathrm{EC}_{1: 5}>0.47 \mathrm{dS} \mathrm{m}{ }^{-1}$ & No depths to $70 \mathrm{~cm}$ & $50-70 \mathrm{~cm}$ & Depths $\geq 40 \mathrm{~cm}$ \\
\hline
\end{tabular}

Exchangeable sodium percentage (ESP); ND = not determined.

Secondly, there was a group of ions were positively correlated with each other. The first survey had three measures of ion concentration-the $\mathrm{EC}_{1: 5}$, and concentrations of $\mathrm{SO}_{4}{ }^{2-}$ and boron. These were significantly $(p<0.001)$ correlated with $r^{2}$ values between 0.421 and 0.774 . The second sampling included measures of the $\mathrm{EC}_{1: 5}, \mathrm{SO}_{4}{ }^{2-}$, boron and four exchangeable cations $\left(\mathrm{Na}^{+}, \mathrm{K}^{+}, \mathrm{Ca}^{2+}\right.$ and $\left.\mathrm{Mg}^{2+}\right)$. Of these, $\mathrm{EC}_{1: 5}, \mathrm{SO}_{4}{ }^{2-}$, boron and exchangeable $\mathrm{Na}^{+}$were most significantly $(p<0.001)$ correlated with $r^{2}$ values between 0.243 and 0.820 . The third sampling included measures of the $\mathrm{EC}_{1: 5}, \mathrm{SO}_{4}{ }^{2-}, \mathrm{Cl}^{-}$and four soluble cations $\left(\mathrm{Na}^{+}, \mathrm{K}^{+}, \mathrm{Ca}^{2+}\right.$ and $\left.\mathrm{Mg}^{2+}\right)$. Of these, $\mathrm{EC}_{1: 5}, \mathrm{SO}_{4}{ }^{2-}, \mathrm{Na}^{+}$and $\mathrm{Cl}^{-}$were most significantly $(p<0.001)$ correlated with $r^{2}$ values between 0.661 and 0.906 . 


\subsubsection{Effects of Treatments}

Treatments had greatest effect at the first time of sampling (Supplementary MaterialsTable S1). With $\mathrm{EC}_{1: 5}$, and $\mathrm{SO}_{4}{ }^{2-}$ there were significant main effects of amendment $(p<0.01)$ and a significant interaction between depth and amendment $(p<0.001)$. There had been $54 \mathrm{~mm}$ of rain and $47 \mathrm{~mm}$ of potential evapotranspiration $\left(\mathrm{ET}_{\mathrm{o}}\right)$ in the 31 days since sowing (the day of implementation of the amendment treatments). Relative to 'nil', the amendments (G, ES and G+ES) were all associated with substantial decreases in the $\mathrm{EC}_{1: 5}$ and $\mathrm{SO}_{4}{ }^{2-}$ concentration at all soil depths measured (Figure 4). At an average soil depth of $60 \mathrm{~cm}$, these decreases were approximately $40 \%$ for $\mathrm{EC}_{1: 5}$ and approximately $60 \%$ for $\mathrm{SO}_{4}{ }^{2-}$ concentration (Figure $4 \mathrm{~A}, \mathrm{~B}$, respectively). Although a salt $\left(\mathrm{CaSO}_{4}\right)$ had been applied to these soils with the $\mathrm{G}$ and $\mathrm{G}+\mathrm{ES}$ amendments, the $\mathrm{EC}_{1: 5}$ and the $\mathrm{SO}_{4}{ }^{2-}$ concentrations were lower than the nil controls, indicating that there had been a net flux of salt below $70 \mathrm{~cm}$ in the 31 days since sowing.

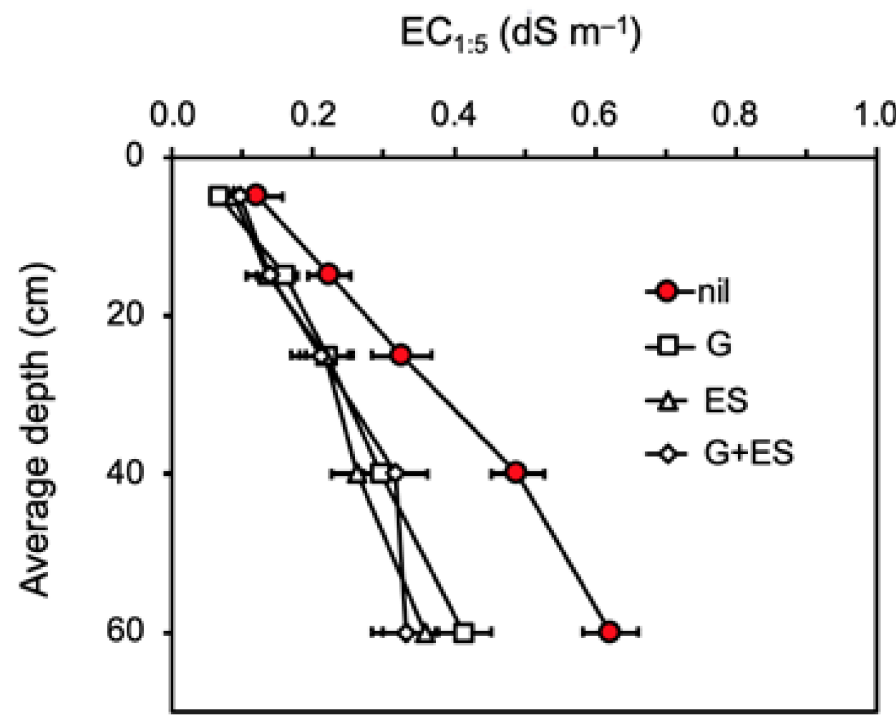

(A)
$\mathrm{SO}_{4}{ }^{2-}\left(\mathrm{mmol} \mathrm{kg}^{-1}\right)$

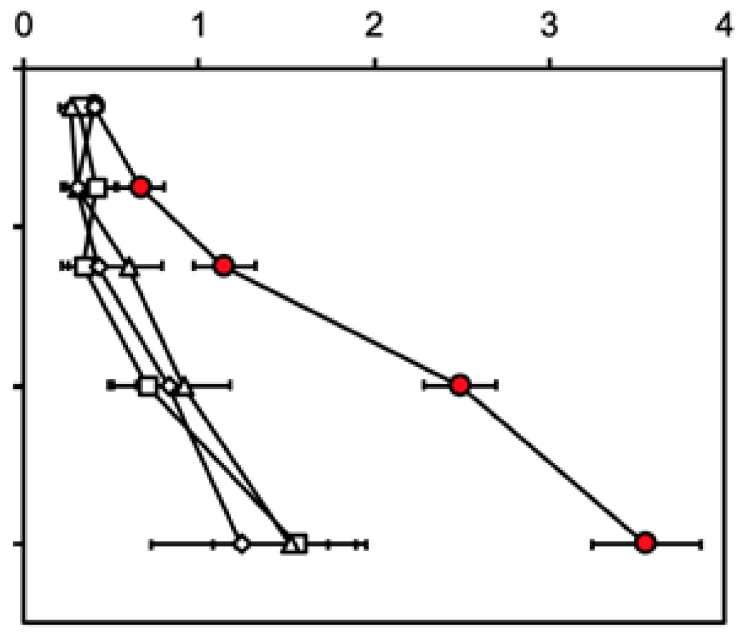

(B)

Figure 4. Effects (at 31 days after sowing) of depth and amendment (nil, G, ES, or G+ES) on: (A) $\mathrm{EC}_{1: 5}$, and (B) $\mathrm{SO}_{4}{ }^{2-}$ concentration. Points are the average of four replicates. Error bars indicate the standard error of the mean. In each case, there was a significant effect of depth $(p<0.001)$, a significant main effect of amendment $(p<0.01)$ and a significant interaction between depth and amendment $(p<0.001)$. Amendments were: nil, gypsum $(G)$, elemental sulfur (ES), and gypsum plus elemental sulfur

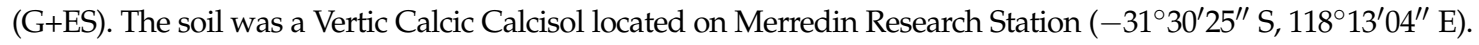

\subsubsection{Correlations between Soil Chemistry and Grain Yield}

The soil at the first and third times of sampling was taken immediately over a furrow; we were therefore able to correlate grain yields from that immediate location with soil chemistry. Tables S4 and S5 in the Supplementary Materials summarize the outcomes of linear correlations between different soil chemical variables and grain yield for the 2019 and 2020 growing seasons, respectively. For 2019 (Table S4-Supplementary Materials), the most important single variables associated with decreasing grain yield were $\mathrm{SO}_{4}{ }^{2-}$ and $\mathrm{EC}_{1: 5}$ at $30-50 \mathrm{~cm}\left(p<0.001 ; r^{2}\right.$ values of 0.472 and 0.337 , respectively). Graphs of these relationships show that grain yield decreased by approximately $40 \%$ as the $\mathrm{SO}_{4}{ }^{2-}$ concentration increased from 0.5 to $3.5 \mathrm{mmol} \mathrm{kg}^{-1}$ (Figure 5A) and as the $\mathrm{EC}_{1: 5}$ increased from 0.1 to $0.6 \mathrm{dS} \mathrm{m}^{-1}$ (Figure $5 \mathrm{~B}$ ). 


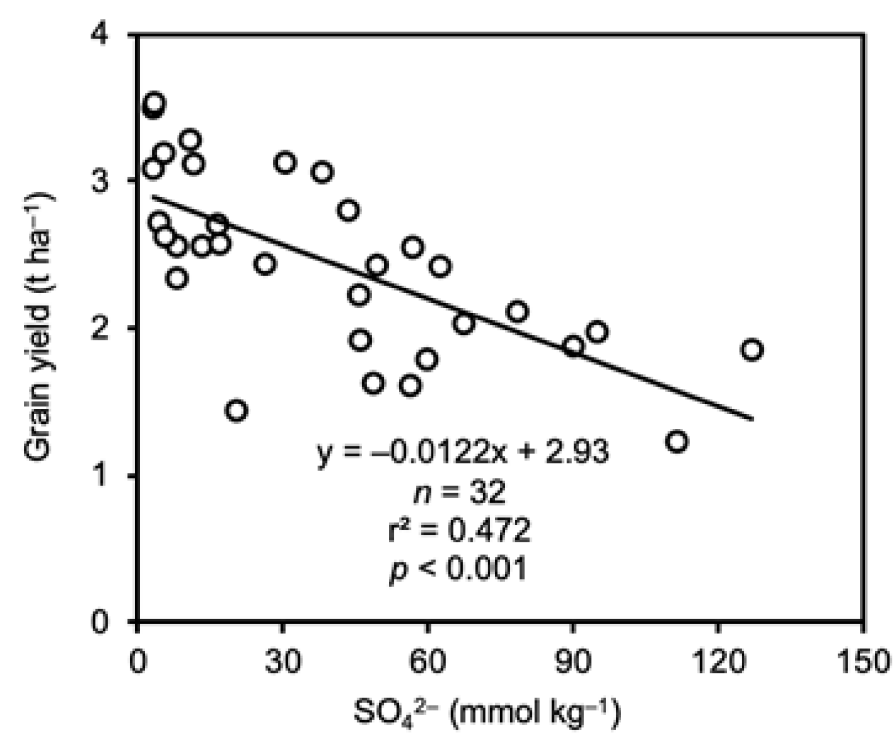

(A)

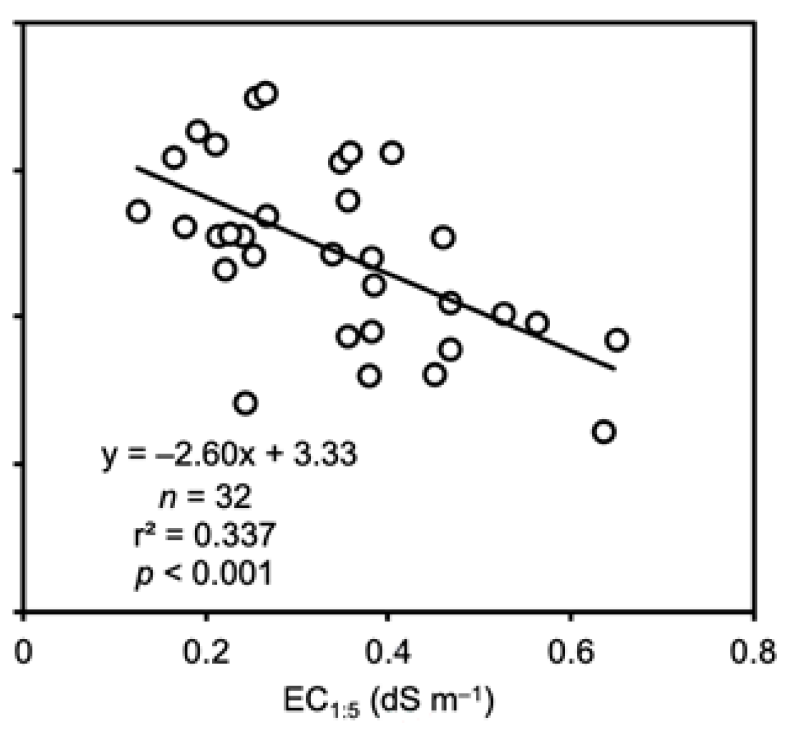

(B)

Figure 5. Best correlations between grain yield (2019) and soil chemistry (first time of sampling): (A) $\mathrm{SO}_{4}{ }^{2-}$ at $30-50 \mathrm{~cm}$, and (B) $\mathrm{EC}_{1: 5}$ at 30-50 cm. The soil was a Vertic Calcic Calcisol located on Merredin Research Station $\left(-31^{\circ} 30^{\prime} 25^{\prime \prime} \mathrm{S}, 118^{\circ} 13^{\prime} 04^{\prime \prime} \mathrm{E}\right)$.

In 2020 (the wetter year), a wider range of soil factors were measured, including soluble ions and soil water. Most of the soil parameters measured did not have significant effects on grain yield (Supplementary Materials, Table S5). However, simultaneous measures of ions and soil water provided us with the opportunity to calculate ion concentrations in the soil solution by assuming that the ion measured was dissolved in the soil water. Concentrations measured in this way are more sensitive indicators of plant stress than concentrations on a soil weight basis because it is the salinity of the soil solution (not the soil) that impacts on plant growth [12]. For 2020 (data summarized in Table S5-Supplementary Materials), the most important single variables associated with decreasing grain yield were gravimetric water at $20-40$ and $40-60 \mathrm{~cm}\left(p<0.001 ; r^{2}\right.$ values of 0.500 and 0.408 , respectively) and $\mathrm{SO}_{4}{ }^{2-}$ in the soil solution at $90-120 \mathrm{~cm}\left(p<0.01 ; r^{2}=0.270\right)$. Graphs of these relationships show that grain yield decreased by $40-50 \%$ as the soil water content at 20-40 and $40-60 \mathrm{~cm}$ decreased from approximately 17 to $12 \%$ dry soil (Figure $6 \mathrm{~A}$ ), and by $40 \%$ as the $\mathrm{SO}_{4}{ }^{2-}$ concentration in the soil solution at $90-120 \mathrm{~cm}$ increased from approximately 20 to $60 \mathrm{mM}$ (Figure 6B).

\subsection{Theme 3-Relationships between Variation in Soil Apparent Electrical Conductivity, Grain Yield and Soil Chemistry}

\subsubsection{EM38 Readings, Treatments and Grain Yield}

EM38 surveys of apparent electrical conductivity in the horizontal orientation $\left(\mathrm{EC}_{\mathrm{ah}}\right)$ were conducted at three locations in each plot in the spring of 2019 and at the same locations in 2020. In 2019, $\mathrm{EC}_{\mathrm{ah}}$ values varied (5th percentile to 95th percentile) from 51 to $84 \mathrm{mS} \mathrm{m}^{-1}$; in 2020 values varied from 43 to $77 \mathrm{mS} \mathrm{m}^{-1}$. However, correlations of readings between 2019 and 2020 showed that the spatial variation in $\mathrm{EC}_{\mathrm{ah}}$ was consistent between years; values collected at the same locations in the spring of 2019 and the spring of 2020 were significantly linearly correlated (Figure $7 ; p<0.001 ; r^{2}=0.58$ ).

The impacts of tillage and amendment treatments on EM38 readings $\left(\mathrm{EC}_{\mathrm{ah}}\right)$ and the relationships between $\mathrm{EC}_{\mathrm{ah}}$ and grain yield are summarized in Figure 8. In 2019, there were significant effects of amendment treatments $(p<0.001)$ and tillage $(p<0.01)$ on $\mathrm{EC}_{\mathrm{ah}}$, but no interaction. In 2020, the effect of amendment was also significant $(P<0.001)$ but there was no significant effect of tillage or interaction. In each year, the $G, E S$ and $\mathrm{G}+\mathrm{ES}$ amendments had $12-18 \%$ lower $\mathrm{EC}_{\mathrm{ah}}$ readings than the nil control (Figure $8 \mathrm{~A}, \mathrm{C}$ ). In 
2019, the mounding plus plastic sheeting treatment had 8\% lower $\mathrm{EC}_{\mathrm{ah}}$ readings than the conventional treatment (Figure 8A).

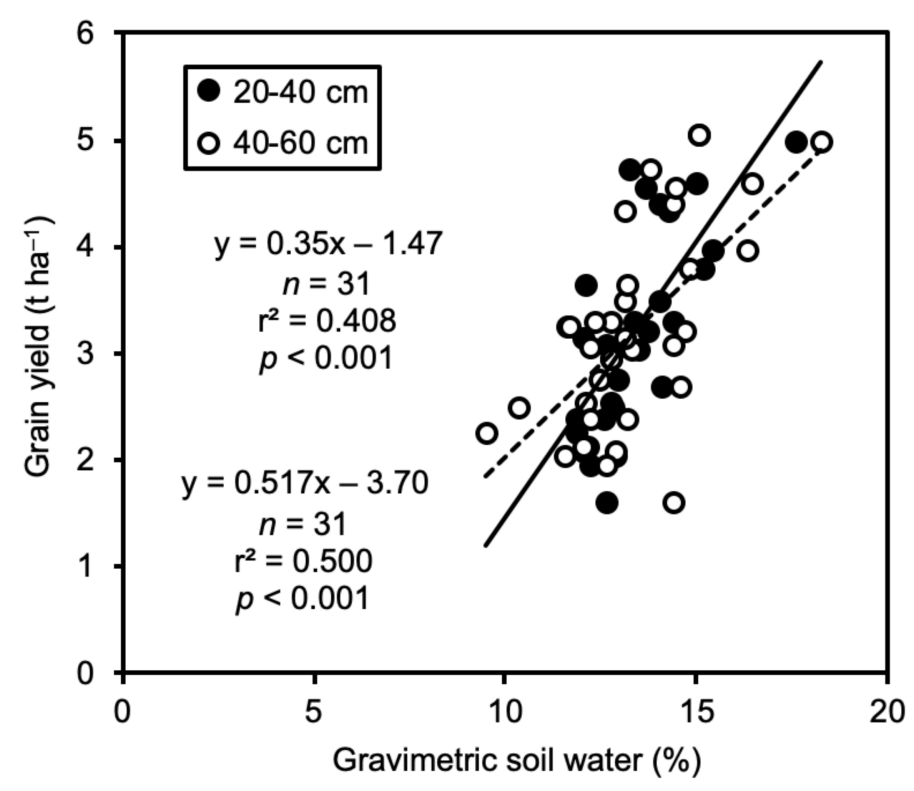

(A)

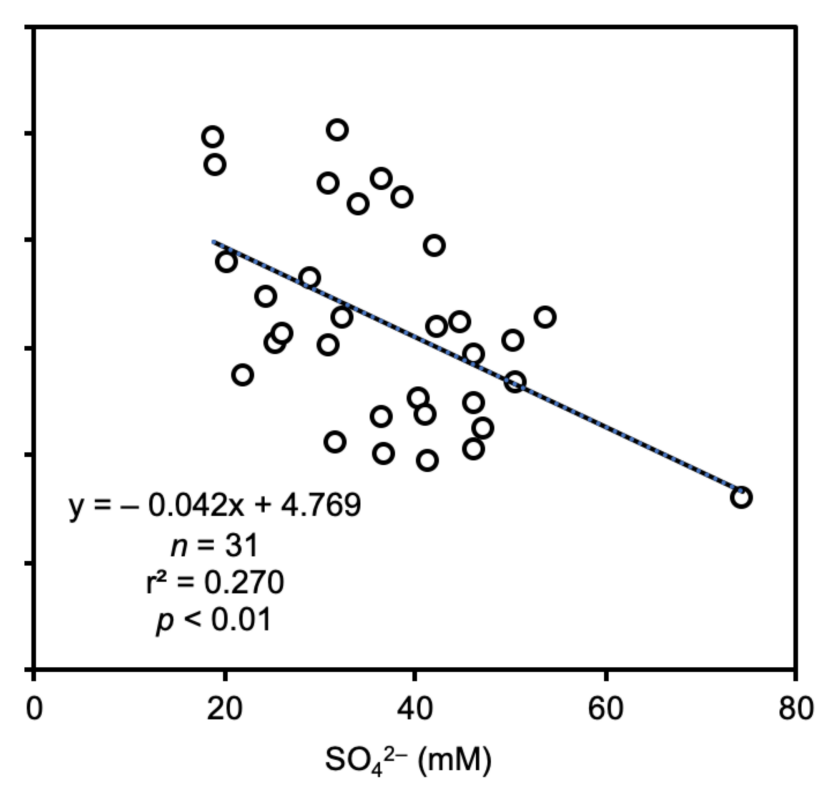

(B)

Figure 6. Best correlations between grain yield and gravimetric soil water or soil chemistry in 2020 (third time of sampling): (A) soil water at $20-40 \mathrm{~cm}$ and $40-60 \mathrm{~cm}$, and (B) $\mathrm{SO}_{4}{ }^{2-}$ in the soil solution at $90-120 \mathrm{~cm}$. The soil was a Vertic Calcic Calcisol located on Merredin Research Station ( $\left.-31^{\circ} 30^{\prime} 25^{\prime \prime} \mathrm{S}, 118^{\circ} 13^{\prime} 04^{\prime \prime} \mathrm{E}\right)$.

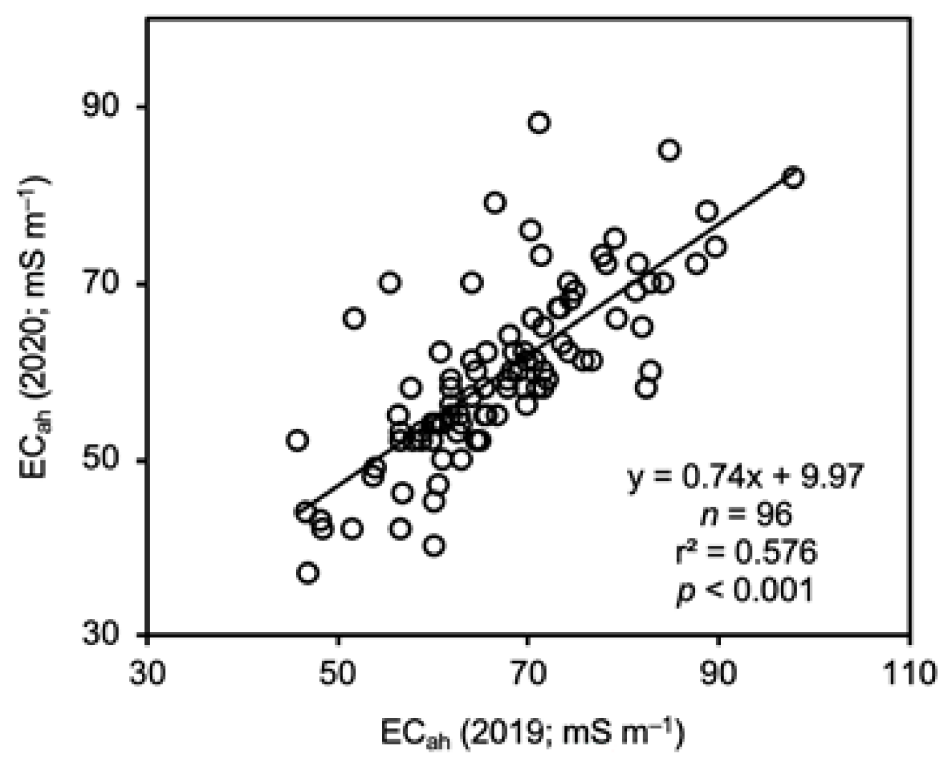

Figure 7. Correlations of EM38 readings in the horizontal orientation ( $\mathrm{EC}_{\mathrm{ah}}$ values) collected on 10 October 2019 and, at the same plot locations, on 21 September 2020. The soil was a Vertic Calcic Calcisol located on Merredin Research Station ( $\left.-31^{\circ} 30^{\prime} 25^{\prime \prime} \mathrm{S}, 118^{\circ} 13^{\prime} 04^{\prime \prime} \mathrm{E}\right)$. 

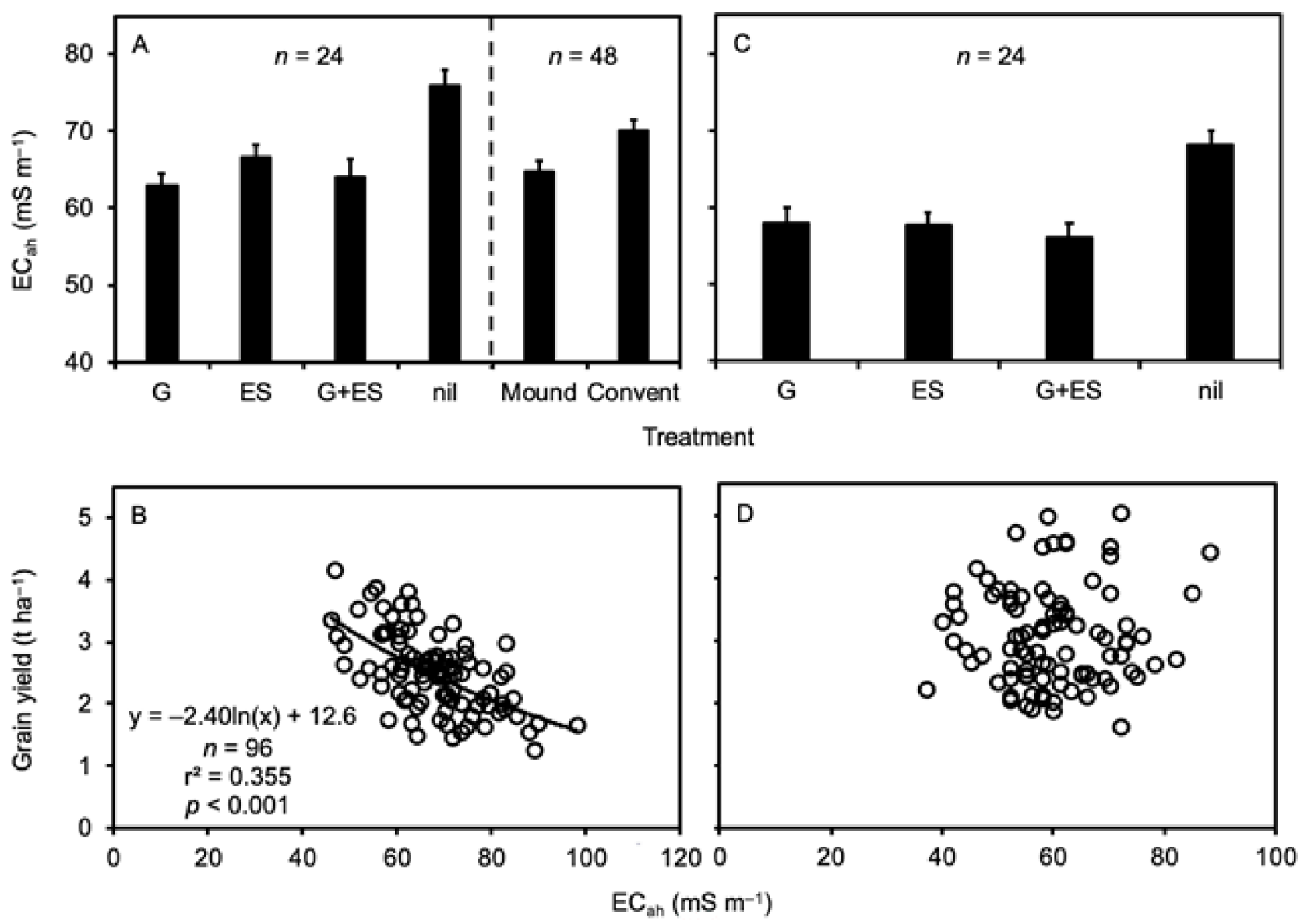

Figure 8. Effects of tillage and amendment treatments on average EM38 readings in the horizontal orientation $\left(\mathrm{EC}_{\mathrm{ah}}\right)(\mathrm{A}, \mathrm{C})$ and the relationship between $\mathrm{EC}_{\mathrm{ah}}$ and grain yield (B,D). Data were collected in $2019(\mathbf{A}, \mathbf{B})$ and $2020(\mathbf{C}, \mathbf{D})$. EC $\mathrm{ah}$ data were collected with the EM38 in the horizontal orientation. Amendments were: nil, gypsum (G), elemental sulfur (ES), and gypsum plus elemental sulfur (G+ES). The soil was a Vertic Calcic Calcisol located on Merredin Research Station $\left(-31^{\circ} 30^{\prime} 25^{\prime \prime} \mathrm{S}, 118^{\circ} 13^{\prime} 04^{\prime \prime} \mathrm{E}\right)$.

Figure $8 \mathrm{~B}, \mathrm{D}$ shows the relationship between $\mathrm{EC}_{\mathrm{ah}}$ readings and grain yield in each year. In 2019, there was a significant logarithmic relationship $\left(r^{2}=0.35 ; p<0.001\right)$ between increasing $\mathrm{EC}_{\mathrm{ah}}$ and declining grain yield. Based on the line of best fit, grain yields were approximately $3.2 \mathrm{tha}^{-1}$ at an $\mathrm{EC}_{\mathrm{ah}}$ of $50 \mathrm{mS} \mathrm{m}^{-1}$, but declined to approximately $1.5 \mathrm{tha}^{-1}$ at an $\mathrm{EC}_{\mathrm{ah}}$ of $100 \mathrm{mS} \mathrm{m}^{-1}$ (Figure $8 \mathrm{~B}$ ). In 2020, there was no significant relationship between $\mathrm{EC}_{\mathrm{ah}}$ and grain yield (Figure 8D).

\subsubsection{EM38 Readings and Soil Chemistry}

EM38 readings could be related to soil chemistry because in 2019, one-third of measurements were taken near the holes of the first time of soil sampling; and in 2020, one-third of measurements were taken near the holes of the third time of sampling $(n=32$ in each case). A statistical summary of the relationships (simple linear correlations) between EM38 readings and soil chemistry for each year are given in the Supplementary Materials Table S6, and Figure 9 shows the strongest relationships. In 2019, $\mathrm{EC}_{\text {ah }}$ readings were most significantly $(p<0.001)$ correlated with $\mathrm{EC}_{1: 5}$ values at $50-70 \mathrm{~cm}\left(r^{2}=0.470\right.$; Figure $\left.9 \mathrm{~A}\right)$, but were also correlated with $\mathrm{EC}_{1: 5}$ at all depth intervals between 10 and $50 \mathrm{~cm}$, and with $\mathrm{SO}_{4}{ }^{2-}$ at all depth intervals between 20 and $70 \mathrm{~cm}$ (Supplementary Materials Table S6). In 2020, $\mathrm{EC}_{\mathrm{ah}}$ readings were most significantly $(p<0.001)$ correlated with $\mathrm{EC}_{1: 5}$ values at $90-120 \mathrm{~cm}$ $\left(r^{2}=0.595\right.$; Figure 9B), but were also correlated with $\mathrm{EC}_{1: 5}$ at all depth intervals between 20 and $90 \mathrm{~cm}$, with $\mathrm{SO}_{4}{ }^{2-}$ at all depth intervals between 40 and $120 \mathrm{~cm}$, and with $\mathrm{Cl}^{-}$at all 
depth intervals between 20 and $120 \mathrm{~cm}$ (Supplementary Materials Table S6). Based on the lines of best fit, in 2019, $\mathrm{EC}_{\mathrm{ah}}$ values increased by $44 \%$ as the $\mathrm{EC}_{1: 5}$ at $50-70 \mathrm{~cm}$ increased from 0.15 to $0.75 \mathrm{dS} \mathrm{m}^{-1}$ (Figure 9A); and in 2020, $\mathrm{EC}_{\mathrm{ah}}$ values increased by $54 \%$ as the $\mathrm{EC}_{1: 5}$ at $90-120 \mathrm{~cm}$ increased from 0.6 to $1.2 \mathrm{dS} \mathrm{m}^{-1}$ (Figure $9 \mathrm{~B}$ ).
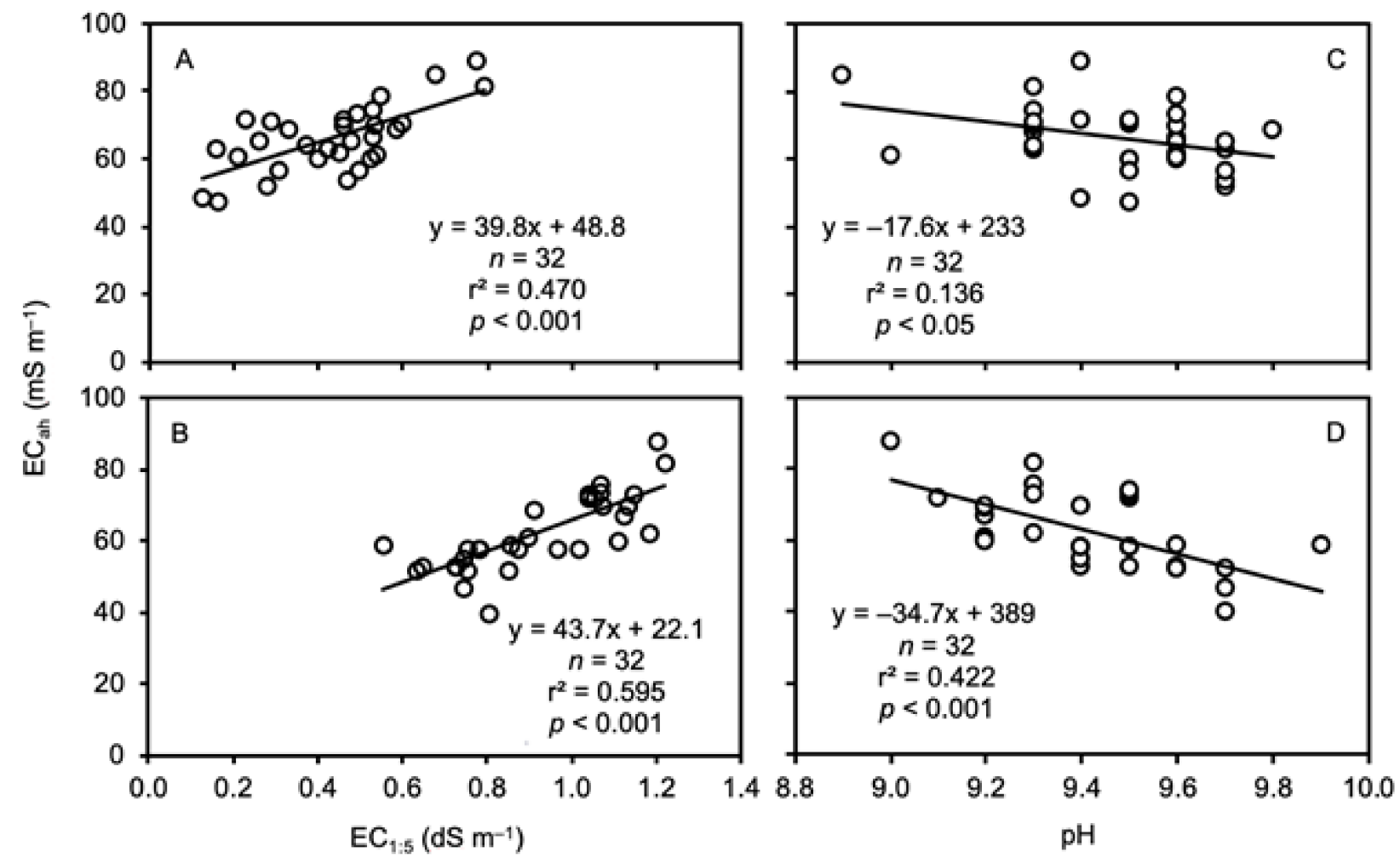

Figure 9. Correlations between EM38 readings in the horizontal orientation $\left(\mathrm{EC}_{\mathrm{ah}}\right)$ and other soil variables: $(\mathrm{A}) \mathrm{EC}_{\mathrm{ah}}$ and $\mathrm{EC}_{1: 5}$ at 50-70 $\mathrm{cm}$ (2019), (B) $\mathrm{EC}_{\mathrm{ah}}$ and $\mathrm{EC}_{1: 5}$ at 90-120 $\mathrm{cm}$ (2020), (C) $\mathrm{EC}_{\mathrm{ah}}$ and pH at 50-70 $\mathrm{cm} \mathrm{(2019);} \mathrm{(D)} \mathrm{EC} \mathrm{ah}$ and pH at 90-120 cm (2020). The soil was a Vertic Calcic Calcisol located on Merredin Research Station $\left(-31^{\circ} 30^{\prime} 25^{\prime \prime} \mathrm{S}, 118^{\circ} 13^{\prime} 04^{\prime \prime} \mathrm{E}\right)$.

Interestingly, in both 2019 and 2020, there were negative relationships between $\mathrm{EC}_{\mathrm{ah}}$ and $\mathrm{pH}$ at 50-70 cm (2019; $p<0.05$; Figure 9C) and 90-120 cm (2020; $p<0.001$; Figure 9D). Based on the lines of best fit, in 2019, $\mathrm{EC}_{\mathrm{ah}}$ values decreased by $19 \%$ as the $\mathrm{pH}$ at $50-70 \mathrm{~cm}$ increased from 9.0 to 9.8 (Figure $9 \mathrm{~A}$ ); and in 2020, $\mathrm{EC}_{\mathrm{ah}}$ values decreased by $36 \%$ as the $\mathrm{pH}$ at $90-120 \mathrm{~cm}$ increased from 9.0 to 9.8 (Figure $9 \mathrm{~B}$ ). Why was this so? It may have been because of the relationship between $\mathrm{pH}$ and $\mathrm{CaCO}_{3}$. It has been previously shown that the concentration of $\mathrm{CaCO}_{3}$ in soils in this region increases in an exponential manner as the $\mathrm{pH}$ of soil increases over the $\mathrm{pH}$ range from 7.9 to 9.7 [5]. The presence of substantial concentrations of $\mathrm{CaCO}_{3}$ (an insoluble salt) would presumably decrease the proportion of more conductive material in the soil profile. In 2020, there was also a significant $(p<0.01)$ negative relationship between increasing $\mathrm{CaCO}_{3}$ at $90-120 \mathrm{~cm}$ and $\mathrm{EC}_{\mathrm{ah}}$ (Supplementary Materials, Table S6).

\section{Discussion}

This research was conducted to determine the impacts of micro-water harvesting and soil amendment on the grain yield of barley in a sodic alkaline soil. In accord with our six hypotheses (H1 to H6), we found that the grain yield of barley was improved by microwater harvesting at the soil surface $(\mathrm{H} 1)$, and by soil amendment with small amounts of gypsum, elemental sulfur or gypsum plus elemental sulfur (H2). Soil amendment with gypsum and $\mathrm{ES}$ was associated with decreased $\mathrm{EC}_{1: 5}$, and $\mathrm{SO}_{4}{ }^{2-}$ concentrations in the soil (H3) and with decreased EM38 readings (H4). Elevated EM38 readings were correlated with decreased grain yield in 2019 (the drier year), but not in 2020 (the wetter 
year) (H5), and were also correlated with elevated $\mathrm{EC}_{1: 5}$ and $\mathrm{SO}_{4}{ }^{2-}$ values (H6). One of the striking features of this work was that we found these effects in barley, a relatively salt-tolerant cereal [42]; the effects of soil desalinization due to soil amendment might have been even stronger if we had used a more salt-sensitive field crop such as field peas or wheat c.f. [14,42] as our test species.

This discussion has four parts, focusing on each of the three themes and finally on the implications of our work for industry.

\subsection{Theme 1-Improving Crop Growth and Grain Yield}

Our results showed significant effects of tillage and amendment on crop yield. These effects are discussed separately.

\subsubsection{Tillage}

Plastic sheeting is widely used in many areas of the world as a mulch to decrease soil evaporation, increase soil temperatures and decrease the leaching of fertilizers; see recent reviews $[43,44]$. Our use of mounding with plastic sheeting to increase micro-water harvesting on soils affected by transient salinity was primarily as a 'proof of concept' treatment. In our research, the beneficial effects of mounding and plastic sheeting were discernible in terms of green cover measurements from the start of each growing season (Figure $3 \mathrm{~A}, \mathrm{C}$ ); and at the end of each growing season, there were increases in grain yield of $22 \%$ and $33 \%$ in 2019 and 2020, respectively, compared with conventional cultivation (Table 3). These yield gains were of a similar order of magnitude to those that have been made with annual crops elsewhere. For example, in a meta-analysis of 474 comparisons published in China, the average yield improvement in wheat through the use of plastic mulch compared to no-mulch was approximately $21 \%$ [45].

\subsubsection{Amendment}

Measures of green cover showed that the beneficial effects of amendment became most significant towards the end of each growing season (Figure 3B,D). Nevertheless, at the end of each growing season, there were increases in grain yield of $28 \%$ and $20 \%$ in 2019 and 2020 , respectively, compared with nil amendment (Table 3). Our yield gains with gypsum were consistent with those achieved in earlier studies under rainfed conditions. In 10 trials at 5 locations in Western Australia between 1983 and 1987, gypsum at $2.5 \mathrm{t} \mathrm{ha}^{-1}$ increased cereal yields by $16-38 \%$ in 6 trials, but the application was non-significant in the others [46]. In New South Wales, at three sites, gypsum at $1.25,2.5$ and $12.5 \mathrm{t} \mathrm{ha}^{-1}$ increased wheat yields by a median of 30,53 and $67 \%$ over the following $2-5$ years [47]. However, in all of these studies, the rates of gypsum application $\left(1.25-12.5 \mathrm{t} \mathrm{ha}^{-1}\right)$ were far higher than used by us ( $50 \mathrm{~kg} \mathrm{ha}^{-1}$ placed within the furrow). We are aware of only one study (conducted on a sodic soil under irrigated conditions) in Pakistan where increases in grain production have been achieved with low rates of gypsum application. In an irrigated experiment on a silty clay loam soil with an $\mathrm{EC}_{1: 1}$ of $4.9 \mathrm{dS} \mathrm{m}^{-1}\left(\mathrm{EC}_{1: 5}\right.$ of $\left.\sim 1.0 \mathrm{dS} \mathrm{m} \mathrm{m}^{-1}\right)$, application of gypsum at the rate of $213 \mathrm{~kg} \mathrm{ha}^{-1}$ produced a $26 \%$ increase in wheat yield [48].

One of the curious features of our work is that there were also benefits to grain yield from soil amendment with S (18\% increase in 2019). This effect could have also been mediated by the synthesis of gypsum. Elemental $\mathrm{S}$ has one major role as a soil amendment: soil acidification $[25,26]$. Acidithiobacillus bacteria oxidize the applied ES in the soil to form sulfuric acid, but in calcareous soils this can react with carbonate to form gypsum $\left(\mathrm{CaSO}_{4} \cdot 2 \mathrm{H}_{2} \mathrm{O}\right)$. The critical reactions are:

$$
\begin{gathered}
2 \mathrm{~S}+3 \mathrm{O}_{2}+2 \mathrm{H}_{2} \mathrm{O}=2 \mathrm{H}_{2} \mathrm{SO}_{4} \\
\mathrm{H}_{2} \mathrm{SO}_{4}+\mathrm{CaCO}_{3}=\mathrm{CaSO}_{4}+\mathrm{H}_{2} \mathrm{O}+\mathrm{CO}_{2}
\end{gathered}
$$




\subsection{Theme 2-Effects of Treatments on Transient Salinity and Soil Chemistry}

Under rainfed conditions, gypsum is dissolved and leached from soils at the rate of approximately $1 \mathrm{t} \mathrm{ha}^{-1}$ for every $120-130 \mathrm{~mm}$ of rainfall [49]. How is it that a rate of gypsum application in the furrow of $50 \mathrm{~kg} \mathrm{ha}^{-1}$ (leachable based on this rule of thumb by approximately $6 \mathrm{~mm}$ of rain) was able to have such a strong effect on crop yield? We suggest that in the sodic alkaline soils of semi-arid Australia, transient salinity can be a major factor limiting grain yield. This creates an osmotic stress to plants after anthesis as the soils dry out and the salinity of the soil solution increases, impacting on crop water relations particularly late in the growing season. The application of a low rate of gypsum might establish a brief 'electrolyte effect' in the soil [50], re-orientating the clay platelets and unblocking soil pores for enough days to restore soil hydraulic conductivity $\left(\mathrm{K}_{\mathrm{s}}\right)$ and allow the movement of salt deeper into the soil profile. The removal of salt from the shallow soil would enable the crop to better manage the adverse water relations of the drying soil during maturation. In the present work, this view is supported by the effects of amendment on measures of soil salinity (Figure 4A,B), and the significant correlations between measures of soil salinity and grain yield (Figures 5 and 6B). Therefore, the effect of the gypsum on $\mathrm{K}_{\mathrm{s}}$ might be ephemeral, but the legacy of even a brief increase in $\mathrm{K}_{\mathrm{s}}$ can persist until the end of the season.

Transient salinity (the salinity of dispersive soils) can be expected to impact most in dry years, when soil moisture is low, so the salinity of the soil solution is high; it will impact least in wet years when soil moisture is high so the salinity of the soil solution is low. The levels of salinity stress at the present site can be illustrated using the data on soluble ion concentrations and soil water reported in the Supplementary Materials Table S3. At the time of the third soil sampling, at a depth of 0-20 cm, the soil had concentrations of soluble $\mathrm{Na}^{+}, \mathrm{Mg}^{2+}, \mathrm{K}^{+}$and $\mathrm{Ca}^{2+}$ of approximately $8.1,4.7,4.3$ and $2.4 \mathrm{mmol} \mathrm{kg}{ }^{-1} \mathrm{DM}$, respectively. If we assume that these ions were dissolved in the soil water $(14.4 \% \mathrm{DM})$, then their concentrations in the soil water would have been approximately 56, 33, 30 and $17 \mathrm{mM}$, respectively, providing us with a total cation concentration of $136 \mathrm{mM}$. Seawater has a cation concentration of approximately $550 \mathrm{mM}$ [51], so at this water content, the soil had an average salinity in the soil solution of $25 \%$ seawater. Using the same method of calculation, at $20-40 \mathrm{~cm}$ depth the total cation concentration would have been $314 \mathrm{mM}$ (57\% seawater), and at 40-60 cm the total cation concentration would have been $602 \mathrm{mM}$ (109\% seawater). If the water content at each of these soil depths had halved towards the end of the growing season, then the salinities would have doubled.

\subsection{Theme 3-Relationships between EM38 Readings, Grain Yield and Soil Chemistry}

Electromagnetic induction has been widely used to survey soil salinity at the landscape and paddock scales [31] and has also been used to account for variation in soil salinity at the plot scale [19,52]. With other spatial techniques such as radiometric analysis and yield mapping, electromagnetic induction has the advantage of being able to survey variation in soils remotely and relatively cheaply $[53,54]$. The use of electromagnetic induction on cropland in Western Australia is relatively recent $[5,55]$. The data contained in Figure 1 are from the largest survey with a DualEM yet conducted at the Research Station. Using these data, we were able to identify a number of locations of high apparent electrical conductivity; our work at one of these showed that crop growth and yield could be increased through the application of low rates of gypsum and elemental sulfur.

With respect to EM38 readings, our work has had three main outcomes. Firstly, there is reproducible patterning in the variation in $\mathrm{EC}_{\mathrm{ah}}$ measurements between years: at the scale of our trial site (an area of approximately $20 \times 40 \mathrm{~m}$ ) plots that had low and high readings in 2019, had similar low and high readings in 2020 (Figure 8). This mirrored the patterning in grain yield in the plots between years: plots that had low and high grain yield in 2019 also had similar low and high grain yields in 2020 (Figure 2). This suggests that much of the variation in apparent electrical conductivity and grain yield is caused by underlying spatial variation. Secondly, there were significant decreases in $\mathrm{EC}_{\mathrm{ah}}$ with soil 
amendment ( 2 years) and with mounding with plastic sheeting (1 year) (Figure 9$)$. With the $\mathrm{EC}_{\mathrm{ah}}$, approximately half the reading is influenced by the upper $40 \mathrm{~cm}$ of the soil profile: the balance is from deeper in the profile [56]. It therefore appeared that our treatments affected the bulk of the soil profile accessible to cereal roots. Thirdly, salinity $\left(\mathrm{EC}_{1: 5}\right)$ and $\mathrm{SO}_{4}{ }^{2-}$ values (from drill samples) were positively correlated with $\mathrm{EC}_{\mathrm{ah}}(p<0.001$ ), and $\mathrm{pH}$ and $\mathrm{CaCO}_{3}$ concentrations in the subsoil (particularly 90-120 cm) were negatively correlated with $\mathrm{EC}_{\mathrm{ah}}\left(p<0.001\right.$ and $p<0.01$, respectively). Variation in $\mathrm{EC}_{\mathrm{ah}}$ values was correlated with variation in yield in the dry year (2019) but not the wet year (2020). The explanation for this effect is not yet clear, but we note that there were strong relationships between $\mathrm{EC}_{1: 5}$, and $\mathrm{Cl}^{-}$and $\mathrm{SO}_{4}{ }^{2-}$ concentrations in the soil and grain yield in 2019 but not in 2020. It may be that the higher rainfall in 2020 maintained high levels of soil hydration that masked much of the adverse effect of transient salinity on crop yield.

\subsection{Implications for Industry}

Salinity in Australia has two principal causes [12]: it can be associated with shallow water tables (water table-induced salinity) and it can be associated with dispersive soils (transient salinity). Shallow water table salinity often causes such severe salinity in soils that the land is only suited to the growth of halophytes [57,58]. In contrast, soils affected by transient salinity are often cropped [12]. Our data suggest that transient salinity can impact on crop yields in semi-arid environments.

Our trial was based on the philosophy that maintaining soil heterogeneity at the scale of the distance between a furrow and mound could have advantages in semi-arid environments in better focusing water around plant roots. We applied G and ES amendments to overcome soil dispersion only in the furrow. Compared to conventional practice, the rate of application of gypsum used in our trial was exceptionally low, $10 \mathrm{~kg} \mathrm{ha}^{-1}$, but focused into the furrow, where the rate there would have been closer to $50 \mathrm{~kg} \mathrm{ha}^{-1}$. This is a much lower gypsum application rate than those used in past studies to ameliorate sodic soils: e.g., $2.5 \mathrm{t} \mathrm{ha}^{-1}$ [46], $12 \mathrm{t} \mathrm{ha}^{-1}$ [20] and $15 \mathrm{t} \mathrm{ha}^{-1}$ [59]. As for S, the amount applied (15.4 kg ha ${ }^{-1}$, or $77 \mathrm{~kg} \mathrm{ha}^{-1}$ in the furrow) was calculated to be sufficient (once oxidized) to break down approximately $20 \%$ of $\mathrm{CaCO}_{3}$ present in the upper $20 \mathrm{~cm}$ of the soil profile. Why should such exceptionally low rates of soil amendment be now yielding benefits to grain yield? Thirty to forty years ago, when most of the gypsum amendment studies cited here were conducted, crops were generally fertilized using single superphosphate, which contained approximately $50 \% \mathrm{CaSO}_{4}$ [60]. A traditional superphosphate application rate of approximately $1 \mathrm{bag}$ per acre $\left(125 \mathrm{~kg} \mathrm{ha}^{-1}\right)$ would therefore have supplied approximately $63 \mathrm{~kg} \mathrm{ha}^{-1}$ of $\mathrm{CaSO}_{4}$. Since the 1980s, crop fertilization strategies have moved strongly towards the use of compound fertilizers that do not contain gypsum. This practice may have moved heavy-textured sodic alkaline soils towards a state of long-term 'gypsum deficiency'.

Our discoveries that sites susceptible to transient salinity can be identified using electromagnetic induction, that the application of low rates of gypsum can cause substantial leaching of salt from these in the year of application, and that such decreases can increase grain yields, could be important in the management of these soils. Farmers and their advisers have tended to regard the application of gypsum to soils as a substantial capital investment, requiring the application of many tonnes per hectare. However, our results suggest a less capital-intensive method of application: small amounts could be applied each year. An efficient method of delivering such small amounts each year might be through the use of compound fertilizers containing gypsum.

\section{Conclusions}

Our work has had a number of highly novel elements. For the first time, research into soil amendment (with gypsum and elemental sulfur) has been joined to micro-water harvesting as a method of increasing crop production on sodic soils. This combination of treatments increased crop yield by $70 \%$ in 2019 and by $57 \%$ in 2020 . Our use of micro-water 
harvesting to overcome transient salinity by better hydrating sodic soils is novel. Our use of exceptionally low rates of gypsum application to improve crop growth under field conditions is novel. Our demonstration of improved crop yields in response to a decrease in transient salinity is novel. Our use of EM technologies to pinpoint where in the landscape soil treatments should be applied is also novel.

One of the recurring themes of agronomic research conducted in non-irrigated semiarid landscapes throughout the world is that crop productivity is most limited by rainfall $[61,62]$. It is now recognized that in many landscapes, this production will also be adversely impacted by climate change [63]. Plant breeders have set themselves the task of increasing grain yields by improving crop water use efficiency, but the rates of progress have been slow; over the period 1960-2010, average crop yields in rainfed environments have increased by less than $1 \%$ per year, with much of these yield increases also being attributable to improved agronomy [62]. Therefore, where will the next major leap in productivity come from? The research conducted in this paper and other papers in this special edition $[64,65]$ suggest that major increases in crop yield may come from overcoming soil constraints such as soil sodicity, alkalinity and acidity.

Supplementary Materials: The following are available online at https:/ /www.mdpi.com/article/ 10.3390/agronomy11040713/s1, Table S1. Variation in selected soil variables (averaged by depth) at the first time of sampling (18 July 2019). Table S2. Variation in selected soil variables including exchangeable cations averaged with depth at the second time of sampling (29 April 2020). Table S3. Variation in selected soil variables including soluble ions averaged with depth at the third time of sampling (13 August 2020). Table S4. Summary statistics for linear correlations between grain yield in 2019 and soil chemical variables at the first time of sampling (18 July 2019). Table S5. Summary statistics for simple linear correlations between grain yield in 2020 and $\mathrm{pH}, \mathrm{EC}_{1: 5}, \mathrm{CaCO}_{3}$, water and ion concentrations in the soil solution. Table S6. Summary statistics for simple linear correlations between $\mathrm{EC}_{\mathrm{ah}}$ readings and soil chemistry in 2019 and 2020.

Author Contributions: Conceptualization, D.H., E.G.B.-L. and D.M. based on an original idea of C.W.; methodology, E.G.B.-L., G.R. and D.M.; formal analysis, E.G.B.-L.; investigation, D.M., R.M., L.W., E.G.B.-L. and G.R.; data curation, E.G.B.-L., D.M. and R.M.; writing-original draft preparation, E.G.B.-L.; writing-review and editing, D.H., G.R. and R.M.; supervision, E.G.B.-L. and D.H.; project administration, D.H.; funding acquisition, D.H. All authors have read and agreed to the published version of the manuscript.

Funding: This research was conducted with the financial support of the Department of Primary Industries and Regional Development and the Grains Research and Development Corporation (Projects DAW00242 and DAW1902-001RTX).

Institutional Review Board Statement: Not applicable.

Informed Consent Statement: Not applicable

Data Availability Statement: Data presented here are available on request from the corresponding author.

Acknowledgments: We gratefully acknowledge the support of the Merredin Research Facility in undertaking the sowing of the trials and in important support with provision of equipment. The DualEM survey of Merredin Research Station was conducted by Precision Agronomics Australia, and Figure 1 was prepared by Karen Holmes. Soil coring was conducted by Joel Andrew (sampling 1 and 2) and Robert Courtney Bennett (sampling 3).

Conflicts of Interest: The authors declare no conflict of interest. The funders had no role in the design of the study; in the collection, analyses, or interpretation of data; in the writing of the manuscript, or in the decision to publish the results. 


\section{References}

1. Hassani, A.; Azapagic, A.; Shokri, N. Predicting long-term dynamics of soil salinity and sodicity on a global scale. Proc. Natl. Acad. Sci. USA 2020, 117, 33017-33027. [CrossRef]

2. Slessarev, E.W.; Lin, Y.; Bingham, N.L.; Johnson, J.E.; Dai, Y.; Schimel, J.P.; Chadwick, O.A. Water balance creates a threshold in soil $\mathrm{pH}$ at the global scale. Nature 2016, 540,567-569. [CrossRef]

3. Rengasamy, P.; Olsson, K.A. Sodicity and soil structure. Aust. J. Soil Res. 1991, 29, 935-952. [CrossRef]

4. Cochrane, H.R.; Scholz, G.; Vanvreswyk, A.M.E. Sodic soils in Western Australia. Soil Res. 1994, 32, 359-388. [CrossRef]

5. Barrett-Lennard, E.G.; Anderson, G.; Holmes, K. High soil sodicity and alkalinity cause transient salinity in south-western Australia. Soil Res. 2016, 54, 407-417. [CrossRef]

6. Chorom, M.; Rengasamy, P.; Murray, R.S. Clay dispersion as influenced by pH and net particle charge of sodic soils. Aust. J. Soil Res. 1994, 32, 1243-1252. [CrossRef]

7. McArthur, W.M. Reference Soils of South-Western Australia; Department of Agriculture: South Perth, Australia, 2004.

8. Nadeau, P.H. Relationships between the mean area, volume and thickness for dispersed particles of kaolinites and micaceous clays and their application to surface area and ion exchange properties. Clay Miner. 1987, 22, 351-356. [CrossRef]

9. Schofield, R.K.; Samson, H.R. Flocculation of kaolinite due to the attraction of oppositely charged crystal faces. Discuss. Faraday Soc. 1954, 18, 135-145. [CrossRef]

10. Shainberg, I.; Letey, J. Response of soils to sodic and saline conditions. Hilgardia 1984, 52, 1-57. [CrossRef]

11. Churchman, G.J.; Skjemstad, J.O.; Oades, J.M. Influence of clay minerals and organic matter on effects of sodicity on soils. Aust. J. Soil Res. 1993, 31, 779-800. [CrossRef]

12. Rengasamy, P. Transient salinity and subsoil constraints to dryland farming in Australian sodic soils: An overview. Aust. J. Exp. Agric. 2002, 42, 351-361. [CrossRef]

13. Maas, E.V.; Grattan, S.R. Crop yields as affected by salinity. In Agricultural Drainage; Agronomy Monograph No. 38; Crop Science Society of America; Soil Science Society of America; American Society of Agronomy: Madison, WI, USA, $1999 ;$ pp. 55-108.

14. Steppuhn, H.; van Genuchten, M.T.; Grieve, C.M. Root-zone salinity: II. Indices for tolerance in agricultural crops. Crop Sci. 2005, 45, 221-232. [CrossRef]

15. Greenway, H.; Munns, R. Mechanisms of salt tolerance in nonhalophytes. Annu. Rev. Plant Physiol. 1980, 31, 149-190. [CrossRef]

16. Munns, R. Comparative physiology of salt and water stress. Plant Cell Environ. 2002, 25, 239-250. [CrossRef]

17. Roundy, B.A. Estimation of water potential components of saline soils of Great Basin rangelands. Soil Sci. Soc. Am. J. 1984, 48, 645-650. [CrossRef]

18. Shalhevet, J.; Hsiao, T.C. Salinity and drought. Irrig. Sci. 1986, 7, 249-264. [CrossRef]

19. Setter, T.L.; Waters, I.; Stefanova, K.; Munns, R.; Barrett-Lennard, E.G. Salt tolerance, date of flowering and rain affect the productivity of wheat and barley on rainfed saline land. Field Crop Res. 2016, 194, 31-42. [CrossRef]

20. Loveday, J. Relative significance of electrolyte and cation exchange effects when gypsum is applied to a sodic clay soil. Aust. J. Soil Res. 1976, 14, 361-371. [CrossRef]

21. Rengasamy, P.; Greene, R.S.B.; Ford, G.W.; Mehanni, A.H. Identification of dispersive behaviour and the management of red-brown earths. Aust. J. Soil Res. 1984, 22, 413-431. [CrossRef]

22. Ellington, A. Effects of deep ripping, direct drilling, gypsum and lime on soils, wheat growth and yield. Soil Till. Res. 1986, 8 , 29-49. [CrossRef]

23. Qadir, M.; Oster, J.D.; Schubert, S.; Noble, A.D.; Sahrawat, K.L. Phytoremediation of sodic and saline-sodic soils. Adv. Agron. 2007, 96, 197-247.

24. Chorom, M.; Rengasamy, P. Carbonate chemistry, $\mathrm{pH}$, and physical properties of an alkaline sodic soil as affected by various amendments. Aust. J. Soil Res. 1997, 35, 149-161. [CrossRef]

25. Hilal, M.H.; Abd-Elfattah, A. Effect of $\mathrm{CaCO}_{3}$ and clay content of alkaline soils in their response to added sulphur. Sulfur Agric. 1987, 11, 15-19.

26. Jaggi, R.C.; Aulakh, M.S.; Sharma, R. Impacts of elemental S applied under various temperature and moisture regimes on $\mathrm{pH}$ and available $\mathrm{P}$ in acidic, neutral and alkaline soils. Biol. Fert. Soils 2005, 41, 52-58. [CrossRef]

27. Hutton, J.T.; Leslie, T.J. Accession of non-nitrogenous ions dissolved in rainwater to soils in Victoria. Aust. J. Agric. Res. 1958, 9 , 492-507. [CrossRef]

28. Hingston, F.J.; Gailitis, V. The geographic variation of salt precipitated over Western Australia. Aust. J. Soil Res. 1976, 14, 319-335. [CrossRef]

29. Suarez, D.L.; Rhoades, J.D.; Lavado, R.; Grieve, C.M. Effect of pH on saturated hydraulic conductivity and soil dispersion. Soil Sci. Soc. Am. J. 1984, 48, 50-55. [CrossRef]

30. Williams, B.G.; Baker, G.C. An electromagnetic induction technique for reconnaissance surveys of soil salinity hazards. Aust. J. Soil Res. 1982, 20, 107-118. [CrossRef]

31. Spies, B.; Woodgate, P. Salinity Mapping Methods in the Australian Context; Department of the Environment and Heritage: Canberra, Australia, 2005.

32. Isbell, R.F.; National Committee on Soil and Terrain. The Australian Soil Classification, 2nd ed.; CSIRO Publishing: Melbourne, Australia, 2016. 
33. IUSS Working Group WRB. World Reference Base for Soil Resources 2014. In International Soil Classification System for Naming Soils and Creating Legends for Soil Maps; World Soil Resource Reports No. 106; FAO: Rome, Italy, 2015.

34. Anderson, G.C.; Peverill, K.I.; Brennan, R.F. Soil sulfur-Crop response calibration relationships and criteria for field crops grown in Australia. Crop Pasture Sci. 2013, 64, 523-530. [CrossRef]

35. Canopeo. Available online: www.canopeoapp.com (accessed on 1 June 2019).

36. Rayment, G.E.; Lyons, D.J. Soil Chemical Methods—Australasia; CSIRO Publishing: Clayton, Australia, 2010.

37. SILO. Available online: www.longpaddock.qld.gov.au/silo (accessed on 5 January 2021).

38. Climate Data Online. Available online: www.bom.gov.au/climate/data (accessed on 5 January 2021).

39. United States Salinity Laboratory Staff. Diagnosis and Improvement of Saline and Alkali Soils; US Department of Agriculture, Agricultural Handbook No. 60; US Government Printer: Washington, DC, USA, 1954.

40. Slavich, P.G.; Petterson, G.H. Estimating the electrical conductivity of saturated paste extracts from 1:5 soil: Water suspensions and texture. Aust. J. Soil Res. 1993, 31,73-81. [CrossRef]

41. Northcote, K.H.; Skene, J.K.M. Australian Soils with Saline and Sodic Properties; Soil Publication No. 27; CSIRO: Melbourne, Australia, 1972.

42. Colmer, T.D.; Munns, R.; Flowers, T.J. Improving salt tolerance of wheat and barley: Future prospects. Aust. J. Exp. Agric. 2005, 45, 1425-1443. [CrossRef]

43. Kasirajan, S.; Ngouajio, M. Polyethylene and biodegradable mulches for agricultural applications: A review. Agron. Sustain. Dev. 2012, 32, 501-529. [CrossRef]

44. Steinmetz, Z.; Wollmann, C.; Schaefer, M.; Buchmann, C.; David, J.; Tröger, J.; Muñoz, K.; Frör, O.; Schaumann, G.E. Plastic mulching in agriculture. Trading short-term agronomic benefits for long-term soil degradation? Sci. Total Environ. 2016, 550, 690-705. [CrossRef] [PubMed]

45. Gao, H.; Yan, C.; Liu, Q.; Ding, W.; Shen, B.; Li, Z. Effects of plastic mulching and plastic residue on agricultural production: A meta-analysis. Sci. Total Environ. 2019, 651, 484-492. [CrossRef] [PubMed]

46. Howell, M. Gypsum use in the wheatbelt. J. Agric. West. Aust. 1987, 28, 40-43.

47. Doyle, A.; Taylor, D.W.; Yates, W.J.; So, H.B.; McGarity, J.W. Amelioration of structurally unstable grey soils in the north-western wheat belt of New South Wales. Aust. J. Exp. Agric. Anim. Husb. 1979, 19, 590-598. [CrossRef]

48. Ali, A.; Arshadullah, M.; Hyder, S.I.; Mahmood, I.A. Effect of different levels of sulfur on the productivity of wheat in a saline sodic soil. Soil Environ. 2012, 31, 91-95.

49. Greene, R.S.B.; Ford, G.W. The effect of gypsum on cation exchange in two red duplex soils. Aust. J. Soil Res. 1985, 23, 61-74. [CrossRef]

50. Quirk, J.P.; Schofield, R.K. The effect of electrolyte concentration on soil permeability. J. Soil. Sci. 1955, 6, 163-178. [CrossRef]

51. Munns, R.; Greenway, H.; Kirst, G.O. Halotolerant Eukaryotes. In Encyclopedia of Plant Physiology; Lange, O.L., Nobel, P.S., Osmond, C.B., Ziegler, H., Eds.; Springer: Berlin, Germany, 1983; Volume 12C, pp. 59-135.

52. Asif, M.A.; Schilling, R.K.; Tilbrook, J.; Brien, C.; Dowling, K.; Rabie, H.; Short, L.; Trittermann, C.; Garcia, A.; Barrett-Lennard, E.G.; et al. Identification of novel salt tolerance QTL in the Excalibur $\times$ Kukri doubled haploid (DH) wheat population. Theor. Appl. Genet. 2018, 131, 2179-2196. [CrossRef]

53. Castrignanò, A.; Wong, M.T.F.; Stelluti, M.; De Beneddetto, D.; Sollitto, D. Use of EMI, gamma-ray emission and GPS height as multi-sensor data for soil characterisation. Geoderma 2012, 175-176, 78-89. [CrossRef]

54. Rodrigues, F.A.; Bramley, R.G.V.; Gobbett, D.L. Proximal soil sensing for Precision Agriculture: Simultaneous use of electromagnetic induction and gamma radiometrics in contrasting soils. Geoderma 2015, 243-244, 183-195. [CrossRef]

55. Rebetzke, G.J.; Chenu, K.; Biddulph, B.; Moeller, C.; Deery, D.M.; Rattey, A.R.; Bennett, D.; Barrett-Lennard, E.G.; Mayer, J.E. A multi-site managed environment facility for targeted trait and germplasm phenotyping. Funct. Plant Biol. 2012, 40, 1-13. [CrossRef] [PubMed]

56. Bennett, S.J.; Barrett-Lennard, E.G.; Colmer, T.D. Salinity and waterlogging as constraints to saltland pasture production: A review. Agric. Ecosyst. Environ. 2009, 129, 349-360. [CrossRef]

57. Barrett-Lennard, E.G.; Bennett, S.J.; Altman, M. Survival and growth of perennial halophytes on saltland in a Mediterranean environment is affected by depth to water table in summer as well as subsoil salinity. Crop Pasture Sci. 2013, 64, 123-136. [CrossRef]

58. Norman, H.C.; Masters, D.G.; Barrett-Lennard, E.G. Halophytes as forages in saline landscapes: Interactions between plant genotype and environment change their feeding value to ruminants. Environ. Exp. Bot. 2013, 92, 96-109. [CrossRef]

59. Sharma, M.L. Physical and physico-chemical changes in the profile of a sodic soil treated with gypsum. Aust. J. Soil Res. 1971, 9 , 73-82. [CrossRef]

60. Cox, W.J. The phosphorus fertilisers: How they compare. J. Agric. West. Aust. 1968, 9, 434-436.

61. French, R.J.; Schultz, J.E. Water use efficiency of wheat in a Mediterranean-type environment. I The relation between yield, water use and climate. Aust. J. Agric. Res. 1984, 35, 743-764. [CrossRef]

62. Richards, R.A.; Rebetzke, G.J.; Watt, M.; Condon, A.C.; Spielmeyer, W.; Dolferus, R. Breeding for improved water productivity in temperate cereals: Phenotyping, quantitative trait loci, markers and the selection environment. Funct. Plant Biol. 2010, $37,85-97$. [CrossRef] 
63. IPCC. Climate Change 2014: Synthesis Report; Core Writing Team, Pachauri, R.K., Meyer, L.A., Eds.; Contribution of Working Groups I, II and III to the Fifth Assessment Report of the Intergovernmental Panel on Climate Change; IPCC: Geneva, Switzerland, 2014; p. 151

64. Anderson, G.C.; Pathan, S.; Easton, J.; Hall, D.J.M.; Sharma, R. Short and long term effects of lime and gypsum application on acid soils in a water-limited environment: 1. Grain yield response and nutrient concentration. Agronomy 2020, 10, 1213. [CrossRef]

65. Hall, D.J.M.; Davis, S.L.; Bell, R.W.; Edwards, T.J. Soil management systems to overcome multiple constraints for dryland crops on deep sands in a water limited environment on the south coast of Western Australia. Agronomy 2020, 10, 1881. [CrossRef] 